\title{
Abnormalities in somatic embryogenesis caused by 2,4-D: an overview
}

\author{
Claudia Garcia ${ }^{1}$ (1) Alex-Alan Furtado de Almeida ${ }^{2} \cdot$ Marcio Costa $^{2} \cdot$ Dahyana Britto $^{1} \cdot$ Raúl Valle $^{3} \cdot$ Stefan Royaert $^{4}$. \\ Jean-Philippe Marelli ${ }^{4}$
}

Received: 29 October 2018 / Accepted: 28 January 2019 / Published online: 18 February 2019

(c) The Author(s) 2019

\begin{abstract}
Somatic embryogenesis is a morphogenetic event where somatic cells have the ability to produce embryos without gamete fusion. It is used as a technique for plant mass propagation. It is a process that has six well defined steps such as induction, expression, development, maturation, germination and plant conversion. These steps are characterized by distinct physiological, morphological and molecular events. Although somatic embryogenesis has been established in several plant species, there remains many problems to be solved. The main problem in somatic embryogenesis is the large number of abnormal embryos produced which cannot germinate nor convert into normal plants. Abnormalities in somatic embryos (SE) can be generated by genetic or epigenetic changes in the DNA. These changes in the DNA can be influenced by external factors such as the use of plant growth regulators and mutagenic substances or stress factors applied to the plant tissue such as high and low temperatures, drought, salinity, and heavy metals. Abnormalities generated by genetic changes in the DNA are hardly reversible; however, abnormalities generated by epigenetic changes may be reversible and the abnormal embryos are able to produce normal plants in most cases. This review focuses on the identification of the main factors that can cause abnormal SE development in different plant species, suggest how SE abnormalities are related to somaclonal variations and identify which genes may be involved with embryo abnormalities. Zygotic embryo abnormalities in Arabidopsis thaliana mutants are listed with the aim to understand the main genetic mechanisms involved in embryo aberrations.
\end{abstract}

\section{Key message}

The abnormalities in somatic embryos are related to the use of 2,4-D in most of the published protocols, this sintetic auxin disrupts the endogenous auxin balance and the auxin polar transportation interfering with the embryo apical-basal polarity.

Keywords Physiological disorders $\cdot$ Embryo-to-plant conversion $\cdot$ Somaclonal variation $\cdot$ Epigenetic $\cdot$ Mutation

\section{Introduction}

Plants propagation by in vitro culture is usually achieved through organogenesis and somatic embryogenesis. Somatic embryogenesis is a morphogenetic event where any somatic cell has the capacity to produce a whole plant without gamete fusion (Fehér et al. 2003). SE can have either multicellular or unicellular origin, emerging from a group of cells or a unique cell, respectively (Maximova et al. 2002). Somatic embryogenesis is produced by in vitro conditions using various plant tissue explant sources and different treatments almost exclusively consisting in supplementing the medium with plant growth regulators (PGR). Other stress treatments such as heavy metal ions, ultraviolet radiation, antibiotic applications, osmotic shocks, dehydration, thermal or cold

Centro de Pesquisas do Cacau, Comissão Executiva do Plano da Lavoura Cacaueira (CEPEC/CEPLAC), Rodovia Jorge Amado, Ilhéus, BA, Brazil

4 Mars Inc, 13601 Old Cutler Road, Miami, FL 33158, USA 
shocks, as well as mechanical or chemical stimuli (Zavattieri et al. 2010) have also been used but remain anecdotal.

The capacity of the plant cell to produce embryos depends on its totipotency, whereby plant cells have the ability to generate new plants (Germana and Lambardi 2016). Somatic embryogenesis can follow two different pathways called direct and indirect somatic embryogenesis (Horstman et al. 2017). The direct pathway occurs when a plant cell produces embryos without callus formation. The indirect pathway requires one additional step for callus formation prior to embryo development (Horstman et al. 2017). Somatic embryogenesis is a tissue culture technique with six steps enumerated as induction, expression, multiplication, development, maturation, germination and plant conversion. These steps are characterized by distinct physiological, morphological, and molecular events (Zavattieri et al. 2010). It has been known that auxins mainly 2,4-dichlorophenoxyacetic acid (2,4-D) is required for somatic embryogenesis induction and embryo multiplication to scale-up the number of embryos which can be potentially produced by indirect somatic embryogenesis (Lloyd et al. 1980; Pasternak 2002; Raghavan 2004; Vondráková et al. 2011) but it is necessary to remove this PGR at the subsequent expression, development and maturation steps because its effect hampers the embryo development and their subsequent conversion into plant (Pasternak 2002; Zavattieri et al. 2010).

The shape of SE can be compared with their equivalent zygotic embryos (ZE) that display the same developmental stages, such as globular, heart, torpedo and cotyledon in dicotyledonous species; globular, scutellar and coleoptilar stages in monocotyledonous species; and early and late embryogenesis in gymnosperm species. However, they are different in the maturation and germination steps because ZE grow and become mature inside the seed surrounded by endosperm, while SE develop from somatic cells without endosperm (Dodeman et al. 1997; Kumar and Van Staden 2017).

There are problems still to be solved in successfully carrying out the somatic embryogenesis process in many plant species, including the processes of maturation, germination and plant conversion. High production of abnormal embryos has been reported in different plant species (Tremblay et al. 1999; Chanatásig 2004; Hashemloian et al. 2008; Vila et al. 2010). The main abnormalities exhibited in SE in different plant species are: fusion of two or more embryos, lack of apical and radical meristems, translucent embryos, multiple cotyledons, and loss of bipolarity (Chanatásig 2004; Hashemloian et al. 2008; El Dawayati et al. 2012; Ruffoni and Savona 2013). Abnormalities in SE may be associated with physiological disorders and/or somaclonal variations (SV) where mutations or epigenetic changes can influence the embryo development and, consequently, the morphology of the resulting plants (Tremblay et al. 1999; Finnegan et al. 2000; Xiao 2006; Bobadilla Landey et al. 2015). The main objectives of this review are to discuss the principal factors that can cause abnormal SE development in different plant species, elucidate how SE abnormalities are related to SV, and identify which genes are potentially involved with embryo abnormalities. ZE abnormalities in some Arabidopsis mutants will be listed in this work with the aim to understand the main genetic mechanisms involved in embryo aberrations.

\section{Abnormal somatic embryo production associated with cell culture conditions and PGA}

Abnormalities in somatic embryogenesis have been reported in different studies during embryo development that are influenced by components in the growth media and environmental conditions. Medium composition and in vitro environmental conditions such as osmotic components, PGR, amino acid sources, culture medium $\mathrm{pH}$, and light intensity and quality (Table 1) can induce changes in the SE phenotype (Zavattieri et al. 2010). Any cell culture condition that stimulates stress in the plant cells can induce different physiological responses and, as a consequence, phenotypic abnormalities (Krishna et al. 2016). Inadequate in vitro conditions in somatic embryogenesis can cause big losses such as low rate of germination and plant conversion of the embryos in a plant production process, which can make these methods inefficient (Garcia et al. 2016). It is also important to highlight that depending of the genotype, variation in culture conditions can improve SE development, germination and plant conversion, so it is often necessary to devise specific protocols.

Auxins are important in many plant species to induce somatic embryogenesis. 2,4-D is the PGR more used for this purpose. However, this auxin can produce epigenetic and genetic changes in the cells, such as methylation and mutations in the DNA (LoSchiavo et al. 1989; LeljakLevanić et al. 2004; Fraga et al. 2012; Fehér 2015). PGR (especially 2,4-D) in high concentration or high exposure of the explant to auxins can block normal embryo development (Cruz et al. 1990; Gaj 2004; Vondráková et al. 2011). Thus, 2,4-D has been related to abnormal SE formation, because in high concentration it disrupts normal genetic and physiological processes in cells treated with this PGR (Stuart and McCall 1992; Tokuji and Masuda 1996; Gaj 2004; Pescador et al. 2008). Normal SE development can be arrested because of long exposition or accumulation of exogenous auxins inside the tissue. As it is in the case of somatic embryogenesis in carrot where exogenous application of 2,4-D was used to induce globular SE. Although 
Table 1 Examples of effects of culture conditions and PGR on the quality of somatic embryos of different species

\begin{tabular}{|c|c|c|c|}
\hline Crop specie & Cell culture condition & Effects & References \\
\hline \multicolumn{4}{|c|}{ Culture conditions that decrease abnormalities in somatic embryos } \\
\hline Juglans regia $\mathrm{L}$ & $\begin{array}{l}\text { Carbohydrate source and polyethyl- } \\
\text { ene glycol }\end{array}$ & $\begin{array}{l}\text { Polyethylene glycol } 7.5 \% \text { and } \\
\text { sucrose } 3.0 \% \text { enhances mor- } \\
\text { phogenesis stimulating embryo } \\
\text { maturation and reducing embryo } \\
\text { abnormalities }\end{array}$ & Jalali et al. (2017) \\
\hline Picea glauca & Polyethylene glycol & $\begin{array}{l}\text { Polyethylene glycol } 7.5 \% \text { improves } \\
\text { the number and quality of SE by } \\
\text { promoting normal differentiation } \\
\text { of the embryonic shoot and root }\end{array}$ & Stasolla (2003) \\
\hline Larix x lepto-europaea & Abscisic acid & $\begin{array}{l}\text { The embryos present dense cyto- } \\
\text { plasmic cells and high rate of cell } \\
\text { division, after } 60 \mu \mathrm{M} \text { ABA treat- } \\
\text { ment the embryos show high stor- } \\
\text { age proteins content and improve } \\
\text { their germination }\end{array}$ & Gutmann et al. (1996) \\
\hline Carum carvi $\mathrm{L}$ & Abscisic acid & $\begin{array}{l}\text { The embryos develop normally, } \\
\text { healthy in appearance with well- } \\
\text { defined cotyledons, unexpanded } \\
\text { radicles and axis free of any pro- } \\
\text { liferations using } 10^{-7} \mathrm{M} \text { ABA }\end{array}$ & Ammirato (1974) \\
\hline Carica papaya $\mathrm{L}$ & Abscisic acid & $\begin{array}{l}\text { ABA } 0.5 \mu \mathrm{M} \text { allows embryogenesis } \\
\text { induction, improves embryos } \\
\text { maturation, and prevents early } \\
\text { germination }\end{array}$ & Cipriano et al. (2018) \\
\hline Crocus sativus $\mathrm{L}$ & $\begin{array}{l}\text { Abscisic acid and polyethylene } \\
\text { glycol }\end{array}$ & $\begin{array}{l}\text { Embryo maturation using polyethyl- } \\
\text { ene glycol 5\% and ABA } 3.8 \mathrm{mM} \\
\text { increases embryo germination and } \\
\text { plant conversion }\end{array}$ & Vahedi et al. (2015) \\
\hline Glycine $\max$ & Carbohydrate source & $\begin{array}{l}\text { Sucrose } 6 \% \text { enhances the conver- } \\
\text { sion of abnormal embryos into } \\
\text { plants }\end{array}$ & Körbes and Droste (2005) \\
\hline Cucumis melo & Carbohydrate source & $\begin{array}{l}\text { Sucrose } 3-6 \% \text { allows germination } \\
\text { of abnormal embryos into plants }\end{array}$ & Gray et al. (1993) \\
\hline Pseudotsuga menziesii & Gelling agents (Gellan gum) & $\begin{array}{l}\text { Gellan gum } 1 \% \text { stimulated embryo } \\
\text { production, and abnormal embryo } \\
\text { development is reduced }\end{array}$ & Lelu-Walter et al. (2018) \\
\hline Acacia Senegal L & L-glutamine & $\begin{array}{l}\text { L-glutamine } 15 \mathrm{mM} \text { stimulates the } \\
\text { maturation of SE and reduces } \\
\text { embryo abnormalities (cup- } \\
\text { shaped structures) }\end{array}$ & Rathore et al. (2012) \\
\hline Abelmoschus esculentus L. Monech & L-glutamine & $\begin{array}{l}\text { L-glutamine } 2 \mathrm{mM} \text { increases plant } \\
\text { conversion reducing embryo } \\
\text { abnormalities }\end{array}$ & Daniel et al. (2018) \\
\hline Carica papaya $\mathrm{L}$ & White light & $\begin{array}{l}\text { White light with intensity of } \\
32 \mu \mathrm{mol} \mathrm{m} \mathrm{m}^{-2} \mathrm{~s}^{-1} \text { improves SE } \\
\text { germination and normal root } \\
\text { development }\end{array}$ & Ascencio-Cabral et al. (2008) \\
\hline Ostericum korean & Low $\mathrm{pH}$ & $\begin{array}{l}\text { Medium with pH } 4.3 \text { improves } \\
\text { embryo morphology reducing the } \\
\text { cup-shaped embryo production }\end{array}$ & Cho et al. (2003) \\
\hline Glycine max & Low $\mathrm{pH}$ & $\begin{array}{l}\text { Medium with pH } 5.5 \text { increases } \\
\text { normal embryo production }\end{array}$ & Lazzeri et al. (1987) \\
\hline Theobroma cacao $\mathrm{L}$ & Myo-inositol & $\begin{array}{l}0.27 \mathrm{M} \text { myo-inositol increased the } \\
\text { embryo-to-plantlet conversion rate } \\
\text { from } 13 \text { to } 16 \% \text { to } 40-48 \%\end{array}$ & Guillou et al. (2018) \\
\hline
\end{tabular}


Table 1 (continued)

\begin{tabular}{|c|c|c|c|}
\hline Crop specie & Cell culture condition & Effects & References \\
\hline \multicolumn{4}{|c|}{ Culture conditions that increase abnormalities in somatic embryos } \\
\hline Pseudotsuga menziesii & Abscisic acid & $\begin{array}{l}\text { ABA } 60 \mu \mathrm{M} \text { blocks cotyledon } \\
\text { development inducing embryo } \\
\text { abnormalities }\end{array}$ & Lelu-Walter et al. (2018) \\
\hline Phoenix dactylifera $\mathrm{L}$ & Abscisic acid & $\begin{array}{l}\text { Concentration of ABA in a range } \\
\text { of } 10-50 \mu \mathrm{M} \text { hampers embryo } \\
\text { development and induces embryo } \\
\text { abnormalities }\end{array}$ & Mazri et al. 2018) \\
\hline Agave angustifolia & Carbohydrate source & $\begin{array}{l}\text { High sucrose concentrations } \\
(8-10 \%) \text { induce embryo abnor- } \\
\text { malities and blocks embryo } \\
\text { development }\end{array}$ & Reyes-Díaz et al. (2017) \\
\hline Eucalyptus globules Labill & Casein hydrolysate and L-glutamine & $\begin{array}{l}\text { Addition of } 0.05 \% \text { casein hydro- } \\
\text { lysate and } 3.4 \mathrm{mM} \text { glutamine } \\
\text { increase abnormal embryo forma- } \\
\text { tion }\end{array}$ & Pinto et al. (2002) \\
\hline Vitis vinifera $\mathrm{L}$ & Benzyladenine & $\begin{array}{l}\text { BAP in a range of } 0.8-3.5 \mathrm{mM} \\
\text { increase abnormal embryos pro- } \\
\text { duction with fascicular shape }\end{array}$ & Ji et al. (2017) \\
\hline Hovenia dulcis & 2,4-dichlorophenoxyacetic acid & $\begin{array}{l}\text { 2,4-D } 4.5 \mu \mathrm{M} \text { induces embryo } \\
\text { abnormalities that cannot germi- } \\
\text { nate in normal plants }\end{array}$ & Yang et al. (2013) \\
\hline Theobroma cacao $\mathrm{L}$ & 2,4-dichlorophenoxyacetic acid & $\begin{array}{l}\text { Depending of the genotype, induces } \\
\text { embryo abnormalities in a con- } \\
\text { centration of } 9.05 \mu \mathrm{M}\end{array}$ & Garcia et al. (2016) \\
\hline Glycine $\max \mathrm{L}$ & 2,4-dichlorophenoxyacetic acid & $\begin{array}{l}\text { 2,4-D } 22.5 \mu \mathrm{M} \text { induces embryo } \\
\text { abnormalities }\end{array}$ & Shoemaker et al. (1991) \\
\hline Capsicum chinense Jacq & 2,4-dichlorophenoxyacetic acid & $\begin{array}{l}\text { 2,4-D } 9.05 \mu \mathrm{M} \text { stimulated fused SE } \\
\text { formation due to the prolonged } \\
\text { exposure to the hormone }\end{array}$ & Lopez-Puc et al. (2006) \\
\hline Rosa chinensis Jacq & White light or dark conditions & $\begin{array}{l}\text { White light with an intensity of } \\
27 \mu \mathrm{mol} \mathrm{m} \mathrm{m}^{-2} \mathrm{~s}^{-1} \text { causes embryo } \\
\text { formation without cotyledons }\end{array}$ & Chen et al. (2014) \\
\hline Daucus carota & White light & $\begin{array}{l}\text { White light with an intensity of } \\
1.4 \mu \mathrm{mol} \mathrm{m}{ }^{-2} \mathrm{~s}^{-1} \text { induces embryo } \\
\text { abnormalities such as multiples } \\
\text { cotyledons, branched radicles and } \\
\text { hypocotyl elongation }\end{array}$ & Michler and Lineberger (1987) \\
\hline Arachis hypogaea & Thidiazuron & $\begin{array}{l}\text { Embryogenic masses cannot } \\
\text { develop into SE when TDZ } \\
\text { is used in a range of } 13.62- \\
45.41 \mu \mathrm{M}\end{array}$ & Joshi et al. (2008) \\
\hline Oncidium sp. & Thidiazuron & $\begin{array}{l}\text { TDZ in a range of } 0.4-13 \mu \mathrm{M} \\
\text { stimulated globular embryos } \\
\text { abnormalities inhibiting their } \\
\text { development and induce necrosis } \\
\text { and dead of the embryogenic } \\
\text { masses }\end{array}$ & Chen and Chang (2000) \\
\hline Rosa chinensis Jacq & Thidiazuron & $\begin{array}{l}\text { TDZ applied in a concentration } \\
\text { of } 11.25 \mu \mathrm{M} \text { to the induction } \\
\text { medium furthered embryogenic } \\
\text { masses formation but the embryos } \\
\text { cannot develop normally becom- } \\
\text { ing necrotic and finally die }\end{array}$ & Chen et al. (2014) \\
\hline
\end{tabular}


embryogenic masses were rinsed with auxin-free medium before to be transferred into the expression medium, 2,4-D accumulation occur inside the globular embryos interfering with their ability to set up the internal auxin gradients that allows cells polarization (Nissen and Minocha 1993). In consequence, these PGR disrupt the normal endogenous auxin balance and the auxin polar transportation, which is important for bilateral symmetry during early plant embryogenesis (Chée and Cantliffe 1989; Venkatesh et al. 2009). Auxin polar transportation in SE when disrupted induces embryo abnormalities (Liu et al. 1993; Abrahamsson et al. 2012; Verma et al. 2018). Research developed with Picea abies identified the influence of polar transportation of indol-3-acetic acid (IAA). A polar transportation inhibitor (1-naphthylphthalamic acid, NPA) was applied at different stages of SE development of P. abies (Larsson et al. 2007). As a result, abnormalities in SE were shown when NPA was used in the initiation and maturation medium. The main abnormalities found were cotyledon fused and irregular cell division in shoot and root meristems (Larsson et al. 2007). Other studies in Arabidopsis thaliana were made inducing a mutation in the auxin transporter. The experiments showed that A. thaliana embryos developed the same morphologies as in $P$. abies, which suggests that the role of polar auxin transport is important for the normal embryo development into plants (Laux 2004).

\section{Abnormalities resulting from the cellular origin}

Somatic embryos arise from a single cell (unicellular origin) or from a group of cells (multicellular origin). Genetic uniformity has been associated with cellular origin, where multicellular origin promotes genetically variable chimeric plants from group of cells transformed genetically. Thus, unicellular origin produces plants that are genetically uniform (Puigderrajols 2001). As mentioned before, SE are produced by direct or by indirect somatic embryogenesis pathways. Direct somatic embryogenesis has a unicellular origin, while indirect somatic embryogenesis has a multicellular origin (Fernando et al. 2001). It is believed that normal SE are developed through direct somatic embryogenesis and abnormal embryos are derived from a group of cells by indirect somatic embryogenesis (Gaj 2004). SE arise from individual epidermic cells directly without callus formation, while indirect somatic embryogenesis requires callus formation before pro-embryonic complexes are formed and subsequent embryo development (Fernando et al. 2001). Somatic embryogenesis can occur either directly or indirectly in the same tissue simultaneously (Puigderrajols 2001; Corredoira et al. 2006). This occurs in Quercus suber L. (cork oak) where SE originated both directly from the individual epidermal cells in the superficial layers without callus formation, and from multiples cells in a compact mass originated from the epidermal cells of the ZE hypocotyls used as explants.

Leaf cultures of Quercus robur tree used to induce somatic embryogenesis also showed the origin of the SE. SE emerged directly from the superficial layers of the epidermis in expanded leaves of $Q$. robur (normal embryos) or from embryonic nodular structures (by indirect somatic embryogenesis) giving rise to abnormal embryos due to the loss of bipolarity (Corredoira et al. 2006). The same pattern was reported in Acca sellowiana somatic embryogenesis where abnormalities developed when SE arose from a group of cells (Pescador et al. 2008). Abnormal embryos might have formed through alteration in cell division patterns of the proembryogenic masses induced by disturbances in auxin transport brought about by exogenous PGR (Gaj 2004). It was reported that abnormalities have been associated with multicellular origin in species such as T. cacao (Maximova et al. 2002), Q. robur (Corredoira et al. 2006), Quercus suber L (Puigderrajols 2001) and Carica papaya L. (Fernando et al. 2001) generally by primary somatic embryogenesis but some SE obtained by secondary somatic embryogenesis have normal development probably due to their unicellular origin (Maximova et al. 2002; Yang et al. 2013). The theory is that SE produced through secondary somatic embryogenesis arises from cells without mutations. Cells with mutation are eliminated by programmed cell death, which is a cellular mechanism that removes DNA damage (Rodríguez López et al. 2010b).

\section{Abnormalities related to SV in somatic embryogenesis}

$\mathrm{SV}$ are known as epigenetic and genetic changes produced in an in vitro propagation program where the resulting plantlets show phenotype and/or genotype variability with regard to the donor plant (Larkin and Scowcroft 1981; Jain et al. 1998; Tremblay et al. 1999; Krishna et al. 2016). Frequency of SV in tissue culture derived plantlets depends on genotype, explant type, culture environment, exogenous PGR, mode of regeneration and culture age (Table 2) (Hitomi et al. 1998; Etienne and Bertrand 2003; Rodríguez López et al. 2010b; Krishna et al. 2016). The main SV shown in tissue culture are variation in the number and structure of the chromosomes, DNA sequence variation, mobile element activation, chromatin remodeling and DNA methylation (Ruiz et al. 1992; Viehmannova et al. 2014).The first report of SV was made by Heinz and Mee (1971) in sugarcane (Heinz and Mee 1971), and after that many reports followed in different species (reviewed in (Krishna et al. 2016)). SV has also been associated with oxidative stress where reactive oxygen species may be involved in DNA alterations of epigenetic or genetic nature (Krishna et al. 2016). 
Table 2 SV type in somatic embryogenesis of important crops

\begin{tabular}{|c|c|c|c|}
\hline Crop specie & Somaclonal variation type & Causes of variation/analysis type & References \\
\hline Glycine $\max L$ & Genetic & $\begin{array}{l}\text { Teratogenic effect on embryo } \\
\text { morphology and development was } \\
\text { generated at } 22.5 \mu \mathrm{M} 2,4-\mathrm{D} \text {. The } \\
\text { progeny of all regenerated plants } \\
\text { was screened for variants (R3 } \\
\text { generation) and found phenotypic } \\
\text { abnormalities associated to the use } \\
\text { of this auxin suggesting mutations }\end{array}$ & Shoemaker et al. (1991) \\
\hline Picea glauca Moench & Genetic & $\begin{array}{l}\text { Long period of in vitro cultivation. } \\
\text { Variegata phenotype was identified } \\
\text { in somatic embryo-derived plant- } \\
\text { lets. Random amplified polymor- } \\
\text { phic DNA (RAPD) analysis was } \\
\text { carried out and identified variation } \\
\text { in a sequence of } 700 \text { pb suggesting } \\
\text { mutation }\end{array}$ & Isabel et al. (1996) \\
\hline Theobroma cacao $\mathrm{L}$ & Genetic & $\begin{array}{l}\text { Mutations associated with tissue cul- } \\
\text { ture protocol. In the protocol a high } \\
\text { concentration of } 2,4-\mathrm{D}(9.08 \mu \mathrm{M}) \\
\text { was used. Simple sequence repeat } \\
\text { (SSR) analysis was carried out } \\
\text { which identified putative chimeric } \\
\text { mutants for slippage mutation or } \\
\text { allele loss across two loci }\end{array}$ & Rodríguez Lopez et al. (2004) \\
\hline Saccharum officinarum $\mathrm{L}$ & Genetic & $\begin{array}{l}\text { Causes unknown. Genotypic stability } \\
\text { in direct SE was evaluated using } \\
\text { RAPD molecular markers. The } \\
\text { analysis revealed polymorphisms } \\
\text { with } 0.89 \% \text { of variation in regener- } \\
\text { ated plants derived through direct } \\
\text { somatic embryogenesis suggesting } \\
\text { mutation }\end{array}$ & Suprasanna et al. (2007) \\
\hline Bactris gasipaes & Genetic & $\begin{array}{l}\text { High concentration of Picloram. } \\
\text { Amplified fragment length poly- } \\
\text { morphism (AFLP) analysis was } \\
\text { carried out to identify mutations. } \\
25 \% \text { of variation was detected in } \\
\text { regenerants cultured on medium } \\
\text { with } 600 \mu \mathrm{M} \text { Picloram }\end{array}$ & Steinmacher et al. (2007) \\
\hline Carica papaya & Genetic & $\begin{array}{l}\text { High concentration of } 2,4-\mathrm{D}(68 \mu \mathrm{M}) \text {. } \\
\text { RAPD analysis was carried out and } \\
\text { the DNA fingerprints revealed both } \\
\text { monomorphic and polymorphic } \\
\text { bands which were associated with } \\
\text { morphological abnormalities in the } \\
\text { resulted plants }\end{array}$ & Homhuan et al. (2008) \\
\hline Theobroma cacao $\mathrm{L}$ & Genetic & $\begin{array}{l}\text { Mutations associated with tissue } \\
\text { culture protocol. In the protocol } \\
\text { was used high concentration of } \\
2,4-\mathrm{D}(9.08 \mu \mathrm{M}) \text {. Cleaved amplified } \\
\text { polymorphic sequence (CAPS) } \\
\text { analysis was used to detect muta- } \\
\text { tion amongst a clonal population } \\
\text { of in vitro cocoa plants. Polymor- } \\
\text { phisms were detected comprising } \\
26 \% \text { of the samples screened }\end{array}$ & Rodríguez López et al. (2010a) \\
\hline
\end{tabular}


Table 2 (continued)

\begin{tabular}{|c|c|c|c|}
\hline Crop specie & Somaclonal variation type & Causes of variation/analysis type & References \\
\hline Olea europaea L cv. Kroneiki & Genetic & $\begin{array}{l}\text { Tissue culture method. High concen- } \\
\text { tration of auxins are used to induce } \\
\text { somatic embryogenesis ( } 24,6 \mu \mathrm{M} \\
\text { IBA and 2,4 } \mu \mathrm{M} 2 \text {-ip). To identify } \\
\text { mutations a RAPD analysis was } \\
\text { carried out in somatic embryogen- } \\
\text { esis plantlets. Regenerated plantlets } \\
\text { were less than } 75 \% \text { similar to the } \\
\text { mother plants suggesting mutations }\end{array}$ & Peyvandi (2010) \\
\hline Smallanthus sonchifolius & Genetic & $\begin{array}{l}\text { Tissue culture method. Indirect } \\
\text { somatic embryogenesis using } \\
4.5 \mu \mathrm{M} 2,4-\mathrm{D} \text { in combination with } \\
0.05-0.5 \mu \mathrm{M} \text { zeatin or } 0.04-0.4 \mu \mathrm{M} \\
\text { N6-benzyladenine (BA) generated } \\
\text { genetic variation. Simple sequence } \\
\text { repeat (ISSR) analysis was carried } \\
\text { out in } 60 \text { regenerated plantlets. } \\
6 \% \text { of the somatic embryogenesis } \\
\text { plants showed genetic variability } \\
\text { compared to the donor plant }\end{array}$ & Viehmannova et al. (2014) \\
\hline Cymbopogon winterianus Jowitt & Genetic & $\begin{array}{l}\text { Method of regeneration. Indirect } \\
\text { somatic embryogenesis using } 2,4-\mathrm{D} \\
\text { in a range of } 6.8-13.6 \mu \mathrm{M} \text { with long } \\
\text { exposition of the explants to this } \\
\text { PGR. Abnormalities were identified } \\
\text { in regenerated plants established in } \\
\text { the field. RAPD analysis was car- } \\
\text { ried out in these plants and genetic } \\
\text { variability was identified }\end{array}$ & Dey et al. (2015) \\
\hline Cuтіпит сутіпит $\mathrm{L}$ & Genetic & $\begin{array}{l}\text { Method of regeneration through indi- } \\
\text { rect somatic embryogenesis using } \\
2,4-\mathrm{D} \text { as source of auxin in a range } \\
\text { of } 2.3-9.08 \mu \mathrm{M} \text { for callus forma- } \\
\text { tion. RAPD analysis was carried } \\
\text { out and presence of polymorphic } \\
\text { bands was detected between regen- } \\
\text { erated plantlets and mother plants }\end{array}$ & Bahmankar et al. (2017) \\
\hline Picea sp. & Genetic & $\begin{array}{l}\text { Long culture periods and cryopreser- } \\
\text { vation method. Culture medium for } \\
\text { somatic embryogenesis initiation } \\
\text { was supplemented with } 9 \mu \mathrm{M} \\
\text { Picloram as source of auxin and BA } \\
\text { as source of cytoquinin in a range } \\
\text { of } 2.2-8.8 \mu \mathrm{M} \text {. Cryopreservation } \\
\text { was carried out using pregrowth- } \\
\text { dehydration method and freezing } \\
\text { with liquid nitrogen. Somaclonal } \\
\text { variation was analyzed using SSR } \\
\text { markers. } 52 \text { different mutations } \\
\text { were identified in both long culture } \\
\text { period ( } 42-44 \text { months) and cryo- } \\
\text { preservation with liquid nitrogen } \\
\text { ( } 2 \text { weeks) of somatic embryogenic } \\
\text { lines }\end{array}$ & Hazubska-Przybył and Dering (2017) \\
\hline
\end{tabular}


Table 2 (continued)

Crop specie

Theobroma cacao $L$

Coffea arabica

Coffea arabica and Coffea canephora Genetic and epigenetic

Hordeum vulgare

Epigenetic

Genetic and epigenetic

Genetic and epigenetic
Somaclonal variation type Causes of variation/analysis type

Mutation and epigenetic changes associated with culture age. SSR markers were used to detect genetic changes. $35 \%$ of regenerated plants exhibited at least one mutation with polymorphisms in two categories (Allele loss and formation of new alleles). For epigenetic changes, methylation-sensitive amplified polymorphism (MSAP) markers were used. The analysis revealed epigenetic divergence between regenerated plants and explant source. Epigenetic and mutation divergences between source of explant and regenerated plants decreased after 10 weeks in culture.

The hypothesis is that secondary somatic embryogenesis in cacao generated SE from cells without mutation or epigenetic change
Tissue culture method. Cellular suspensions using $2.3 \mu \mathrm{M}$ 2,4-D as source of auxin induce genome and epigenome instability. The use of low concentration of $1.36 \mu \mathrm{M}$ 2,4-D in suspension cultures reduces somaclonal variations in the resulted somatic embryoderived plantlets. Molecular AFLP and MSAP analysis in regenerated plantlets showed that polymorphism between mother plants and regenerated plantlets by somatic embryogenesis was extremely low (Less than 0.18\%)

Culture age and method of culture. Multiplication of cell suspension is carried out in liquid medium supplemented with $2.26 \mu \mathrm{M} 2,4-\mathrm{D}$, $4.92 \mu \mathrm{M}$ indole-3-butyric acid (IBA) and $9.84 \mu \mathrm{M}$ isopentenyladenine (iP). Age of embryogenic cells suspension induces somaclonal variation. Morphological analysis was carried out in somatic embryo-derived plants established in the field. Somaclonal variation increase from 6 to $25 \%$ in plantlets produced from cell suspension aged 6 to 12 months

Long exposition to 2,4-D in a concentration of $9.0 \mu \mathrm{M}$. Phenotypic variants were detected in the regenerated plantlets, but in the cellular analysis mitotic alterations were not detected. This suggests epigenetic variation
Landey et al. (2013)

Etienne and Bertrand (2003)

Ruiz et al. (1992)

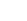

\section{References}

Rodríguez López et al. (2010b) 
Table 2 (continued)

\begin{tabular}{|c|c|c|c|}
\hline Crop specie & Somaclonal variation type & Causes of variation/analysis type & References \\
\hline Cucurbita pepo $L$ & Epigenetic & $\begin{array}{l}\text { Long exposition of 2,4-D } 4.5 \mu \mathrm{M} \\
\text { and } \mathrm{NH} 4 \mathrm{Cl} \text { in a range of } 1-0 \mathrm{mM} \\
\text { blocks embryos development. } \\
\text { Genomic DNA digestion and ran- } \\
\text { dom PCR amplification was carried } \\
\text { out to analyze DNA methylation. } \\
\text { High levels of DNA methylation } \\
\text { were observed in cell lines cultured } \\
\text { on medium supplemented with } \\
\text { 2,4-D and } \mathrm{NH} 4 \mathrm{Cl}\end{array}$ & Leljak-Levanić et al. (2004) \\
\hline
\end{tabular}

Phenotypic abnormalities related to genetic nature were identified in somatic embryo-derived plantlets (Table 2). Variations in the plant architecture and leaf morphology are some of the most important features identified in coffee somatic embryo-derived nursery plants after 12 months of development. The predominant abnormalities were angustifolia, variegata and dwarf found in these somatic embryogenic plants. Chromosome number were evaluated in the abnormal plants and it was reduced compared with the number of chromosomes of the mother plants (Bobadilla Landey et al. 2015). AFLP markers were also used to analyze DNA variations in coffee somatic embryos-derived plants. The molecular analysis revealed differences in polymorphisms profiles between plantlets and the donor plants (Landey et al. 2013). Similar morphological variations were reported in papaya plants in the field where production was compromised. Somatic embryogenesis plants obtained by the indirect pathway showed abnormalities in number of flowers, floral length, number of fruits, fruit length and fruit morphology. Papaya embryogenic callus was grown in induction medium supplemented with $15 \mathrm{mg} \mathrm{L}^{-1}$ of 2,4-D. Probably the high concentration of 2,4-D used to induce embryogenic callus had a strong influence in genetic variations and in consequence morphological abnormalities. Therefore, molecular analysis was done using RAPD. The results revealed differences in band patterns between somatic embryo-derived plantlets (emerged from callus) and the donor plant due to mutations in the DNA (Homhuan et al. 2008; Aydin et al. 2016).

Abnormalities were also identified in somatic embryoderived plants associated with epigenetic changes (Table 2). Epigenetic is any process that changes gene activity due to alterations in the chemistry of the DNA without sequence variations (Zhang 2013; Kumar and Van Staden 2017). During the various plant development phases, the gene expression is programmed to allow organ formation. This program must be erased and replaced with a new program within hours, days or weeks following their exposure to the in vitro culture conditions that induce somatic embryogenesis. These events are mediated by the interaction among endogenous and exogenous hormone levels, other components in the culture medium and the environment conditions (De-la-Peña et al. 2015). PGA and stressful environmental conditions applied to cells in in vitro culture affect the processes of histone modification, chromatin structural reorganization and DNA methylation, which in turn can change the overall gene expression patterns (De-la-Peña et al. 2012; Ruffoni and Savona 2013, Us-Camas et al. 2014; Fehér 2015). These epigenetic mechanisms are important factors that have strong influence in organism phenotypes and consequently in SE abnormalities (Zhang 2013).

DNA methylation is an epigenetic event that consists of the addition of a methyl group at the $5^{\prime}$-position of the cytosine in the contexts of $\mathrm{CpG}\left(5^{\prime}-\mathrm{C}-\right.$ phosphate $\left.-\mathrm{G}-3^{\prime}\right)$, $\mathrm{CHG}$ or $\mathrm{CHH}$ (with $\mathrm{H}$ being $\mathrm{A} / \mathrm{T} / \mathrm{G}$ ) repetitive sequences in the plant DNA (Finnegan et al. 2000; Zhang et al. 2010). In tissue culture, mainly in somatic embryogenesis there is a growing appreciation that DNA methylation is an important mechanism influencing SV in the resultant plantlets altering their physiology and phenotype and it can be inherited by generations (Chakrabarty et al. 2003; Tchorbadjieva and Pantchev 2004; Francischini et al. 2017). Chromatin remodeling is also related to $\mathrm{SV}$ when sudden variation in the gene expression can cause phenotypic and physiologic alterations in the plantlets generated by in vitro culture. Chromatin adopts two major stages, heterochromatin (chromatin more compacted) and euchromatin (chromatin more relaxed) when the histones are methylated or acetylated, respectively. Heterochromatin, different to euchromatin, blocks DNA transcription (Kim and Kaang 2017). DNA methylation and chromatin remodeling interact mutually in regulating gene expression.

Abnormalities in plantlets induced by epigenetic factors have been reported in different crops (Kitimu et al. 2015; Ghosh et al. 2017; Goyali et al. 2018). In Agave angustifolia Haw., albinism was related to the tissue culture environment where the missing of color in leaves was correlated with high levels of DNA methylation (Duarte-Aké et al. 2016). In Elaeis guineensis Jacq. (oil palm) the mantled phenotype was identified in plants propagated by somatic 
embryogenesis. This phenotype is a homeotic flowering abnormality that results in plant sterility and in consequence lower oil yields (Morcillo et al. 2006). In that study the expression of two genes ( $E g M 39 A$ and $E g I A A I)$ displayed increased transcription accumulation in auxin-treated callus as a consequence of DNA methylation. The auxins used in this experiment were 2,4-D and naphthalene acetic acid. It was demonstrated that exogenous auxin induced changes in DNA methylation and this change generated abnormalities in plants.

Some research has been developed to evaluate DNA methylation in somatic embryogenesis using methylation inhibitors, such as 5-azacytidine (5-azaC). 5-azaC is a potent drug that has the ability to incorporate itself into DNA, trap DNA methyltransferases (DMNTs) and lead them to their degradation, promoting DNA hypomethylation (Issa and Kantarjian 2009). It has been shown that plants submitted to treatments with 5 -azaC produce abnormalities such as dwarfism and it can also induce early flowering and vegetative growth inhibition (Kondo et al. 2006). Embryogenic callus of Coffea canephora treated with 5 -azaC in different points during the whole process showed some interesting results. 5-azaC added every 7 days in the somatic embryogenesis cultures showed embryo formation inhibition, but when the drug was added at the 21 day of culture it increased pro-embryogenic masses proliferation preventing SE development (Nic-Can et al. 2013). In this research, it was noted that the methylation level decreased when the drug was added to the culture medium independently of the phase of the somatic embryogenic process where it was applied. Methylation levels in SE decreased during embryo development and maturation but, when somatic embryogenesis is starting methylation levels are higher (Nic-Can et al. 2013). Similar results were obtained in Medicago truncatula where it was observed that the use of 5-azaC in somatic embryogenesis cultures decreased methylation levels and this interrupted SE development (Santos and Fevereiro 2002). Differently, the use of 5 -azaC in somatic embryogenesis in other crops such as Acca sellowiana maintained high methylation levels, but these levels of methylation did not allow embryo development and plant conversion (Fraga et al. 2012). Those results suggest the important dynamic role of DNA methylation in SE induction, development and conversion to true-to-type plants.

Somatic and ZE morphology has also been associated with PIN-like proteins regulated by DNA methylation (Xiao 2006; Fraga et al. 2016). In zygotic embryogenesis DNA methylation was related with PIN1 expression, which in turn, are necessary to establish auxin transport in the embryo (Xiao 2006). By contrast, for induction of somatic embryogenesis, the DNA methylation levels are affected by PGR addition to the culture medium and, in consequence, the transcription of PIN-like proteins can be down-regulated and auxin polar transportation affected, blocking the right SE morphogenesis (Friml et al. 2003). In other studies, DNA methylation in the mother plant, and normal and abnormal in vitro plantlets of sugarcane was measured using the technique MSAP. Sixteen selective primers for $E c o \mathrm{RI} / M s p \mathrm{I}$ and EcoRI/HpaII restriction enzymes were used. Abnormal plantlets were identified as somaclonal variants. Genetic similarity between mother plant and abnormal plantlets was compared and the range of similarity was $87.7-91.1 \%$ for EcoRI/MspI and 92-95\% for EcoRI/HpaII. These results confirm that there is a relationship between abnormalities in in vitro plantlets and DNA methylation (Francischini et al. 2017).

\section{Molecular view of abnormalities in plant embryogenesis}

Plant embryogenesis depends on a sophisticated morphogenetic program where several genes, mainly those that encode transcription factors (TF), regulate all the process from zygote formation until embryo maturation. Zygotic and SE show several similarities in the morphogenetic program that control them, for example the HAEM ACTIVATOR PROTEINS 3 (HAP3) a multimeric transcriptional activator complex, where the TF LEAFY COTYLEDON1 (LEC1) and LEAFY COTYLEDON LIKE (LIL) are members (Smertenko and Bozhkov 2014). LECI and LIL are important regulators of early zygotic embryogenesis in the cotyledon cell identity and suspensor cell maintenance, and in later stages these TF control maturation initiation and maintenance, as well as precocious germination (West et al. 1994). Beside the role of LECI and LIL in zygotic embryogenesis, they are essential for somatic embryogenesis induction and embryo maturation. Along with LECI and LIL, LEC2 and FUSCA3 also members of the $L E C$ genes family are important $T F$ that regulate embryogenesis development (Harada 2001; Guo et al. 2013). Lec mutants in A. thaliana zygotic embryos exhibit defects in cotyledons morphology and problems in maturation and desiccation tolerance. Mutations in LECl and FUSCA3 (FUS3) genes cause embryo lethality due to loss of desiccation tolerance during late seed development, while mutations in the $L E C 2$ gene block embryo development (Harada 2001; Stone et al. 2001). In somatic embryogenesis lec1, lec2 and fus 3 mutants submitted to in vitro culture formed SE in low frequency compared with wildtype cultures, and double (lec1 lec2, lec1 fus3, lec2 fus3) and triple (fus3 lecl lec2) mutants show total somatic embryogenesis repression (Gaj et al. 2005). LEC 2 gene has also an important role in zygotic and somatic embryogenesis in $T$. cacao. Young cacao leaves and ZE cotyledons were transformed using Agrobacterium tumefaciens to overexpress the 
TcLEC2 gene. After that, somatic embryogenesis induction was carried out in the transformed tissues. Surprisingly, high frequency of SE were induced, but they expressed developmental and morphological abnormalities keeping the embryos at the globular and heart stage, therefore, cotyledon development was compromised, and new secondary SE came out of the malformed cotyledons (Zhang et al. 2014). LEC2 gene has the capacity to cause changes in auxin activity (Ledwoń and Gaj 2009) through activation of the YUCCA2 (YUC2) and YUC4 genes involved in auxin biosynthesis via the tryptophan-dependent pathway (Yamamoto et al. 2007; Stone et al. 2008).

After embryogenesis induction, zygotic and somatic cells divide asymmetrically producing an apical and basal cell. This spatial cell distribution results in the apical-basal axis formation where the PGR auxin plays an important role together with proteins such as WOX and PINFORMED. The WUSCHEL (WUS)—related homeobox (WOX) homeo domain gene family codified an important TF that is involved in the earlier phases of ZE development and also regulates the lateral organ development in plants (Haecker 2004). WOX genes are expressed in the singlecell zygote when the embryo apical-basal axis is forming in angiosperm plants, such as A. thaliana (origin of early pattern divisions). The apical daughter cell of the zygote gives origin to the apical meristem, cotyledons, hypocotyl, embryonic root and root meristem. The basal daughter cell gives origin to the suspensor. Both cell fates occur through asymmetric divisions (Haecker 2004). Three important WOX genes are activated in the apical and basal cell division patterns, i.e., the WOX2 and WOX8/9 respectively (Breuninger et al. 2008).The WOX2, WOX8 and WOX9 genes were also expressed in early SE development, but their expression decreased in SE maturation (Palovaara and Hakman 2009, Su et al. 2009; Bouchabké-Coussa et al. 2013; Zhu et al. 2014; Kumar and Van Staden 2017). Abnormalities in the suspensor formation and lack of protoderm were the main features in SE produced from WOX2 transgenic cell lines (35S:WOX2i) in the gymnosperm plant Norway spruce (Picea abies L. Karst) (Zhu et al.

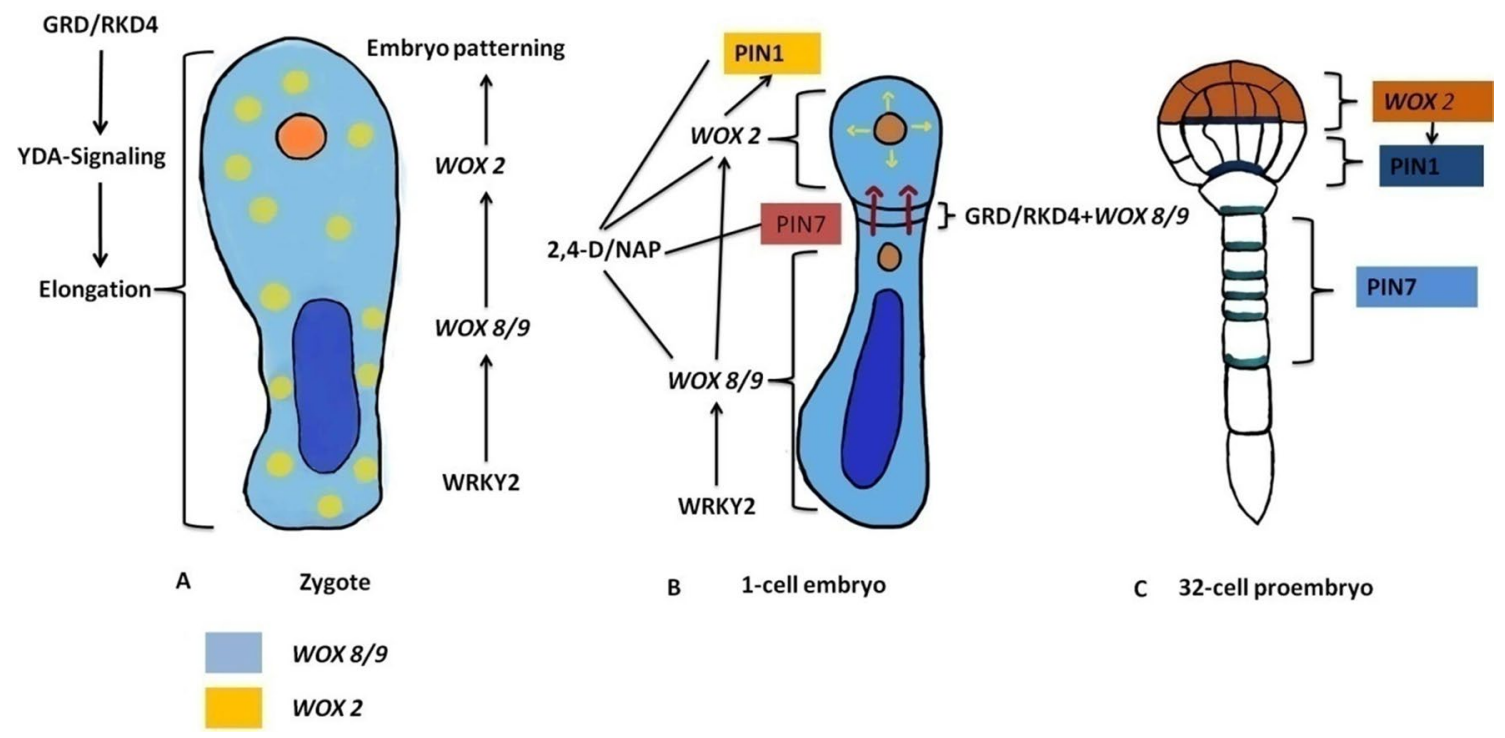

Fig. 1 Model of the zygotic elongation and asymmetric division in Arabidopsis thaliana. a YDA-signaling activation by GRD/RKD4 protein through unknown mechanism to zygote elongation (Jeong et al. 2011; Waki et al. 2011; Mursyanti et al. 2016), and the embryo patterning activation by WRKY2 protein, which in turn activates the WOX 8/9 gene expression (Ueda et al. 2011). Subsequently, WOX 2 is activated by WOX $8 / 9$ proteins to start the embryo polarization (Breuninger et al. 2008). b The WRKY/WOX pathway promotes polar organelle localization where the small apical daughter cell is formed by dense cytoplasm and the bigger basal daughter cell is formed by a large vacuole (Ueda et al. 2011; Zhang and Laux 2011). Exogenous application of 2,4-D/NAP blocks the WOX genes and the auxin polar transportation via PIN proteins, it results in the disruption of embryos asymmetric division, and in the production of several embryo abnormalities (Friml et al. 2003; Palovaara and Hakman 2009). WOX 2 genes are expressed in the apical daughter cell of the 1-cell embryo, while the WOX $8 / 9$ genes are expressed in the basal- cell (Breuninger et al. 2008). The GRD/RKD4 works in cooperation with the WOX $8 / 9$ genes in the establishment of embryo polarity (Jeong et al. 2011; Waki et al. 2011; Mursyanti et al. 2016). Lossof-function of the GRD gene induces the reduction of the elongation of the zygote and abnormal early cell division (Jeong et al. 2011). c WOX 2 affects auxin polar transport and distribution in the 32-cell pro-embryo via activation of PIN1 protein (Friml et al. 2003).. PIN7 proteins are localized in the apical side of the suspensor cells facing the pro-embryo (Friml et al. 2003). These proteins lead the auxin transport from the suspensor to the pro-embryo since 1-cell embryo onwards (Friml et al. 2003). The solid lines represent inhibition and solid arrows indicated activation. Vacuoles (dark blue ovals), nuclei (brown circles) are indicate in a, b. The WOX 2 and WOX 8/9 expression are indicate in color-code as shown in a, c. PIN1 and PIN7 distribution in the 1-cell and 32-cell embryos are indicated in color-code shown in $\mathbf{b}, \mathbf{c}$ 
2016). Aberrant cell division in basal cells of the zygote, and apical-basal polarity were completely lost in SE from WOX8/9 transgenic cell lines of P. abies (Zhu et al. 2014). Embryos development in wox8wox9 double mutants of $A$. thaliana is arrested, resulting in abnormal development in the suspensor and the pro-embryo, suggesting that WOX 8 and WOX9 gene expression influence the expression of the WOX2 gene (Fig. 1a) (Breuninger et al. 2008). WOX genes have an evolutionary conserved function in apicalbasal axis formation in angiosperms and gymnosperms. Loss-of-function of these TF in zygotic and SE generates serious problems in embryo development.

The WRKY proteins are a superfamily of zinc-finger domain TF specific to plants, which are involved in environmental and developmental interactions (Eulgem et al. 2000). These proteins are important in cell fate and embryonic patterning because they regulate WOX8 and WOX9 expression in the basal embryo lineage (Fig. 1a) (Ueda et al. 2011). The WOX 8 and WOX9 carry an intron fragment cisB with a canonical W-box (TTGACC/T) where the WRKY proteins bind with high affinity (Eulgem et al. 2000; Ueda et al. 2011). WOX8/9 expression in the wrky2-1 mutants is completely lacking, and the uppermost cells of the basal lineage of these mutants and secondary pro-embryo-like structures arisen from them divided abnormally (Ueda et al. 2011). The zygote polarity is established by the WRKY2-WOX8/9 transcription cascade through the organelle organization (vacuolization of the basal daughter cell in the zygote); thus, it establishes the asymmetric cell division in the zygote with the subsequent WOX2 gene activation in the embryo proper by WOX8/9 proteins, which in turn activates the PINI gene and the correct auxin transport and distribution in the 1-cell embryo stage (Fig. 1b, c) (Ueda et al. 2011; Zhang and Laux 2011).

Along with the WOX TF the PINFORMED (PIN) genes that codified PIN1, PIN4 and PIN7 proteins are involved in the formation of the apical-basal axis of the embryo providing the intercellular transport of the auxin (Tvorogova et al. 2015). PIN1 and PIN7 proteins act directly in the apicalbasal auxin transport in early embryogenesis. At the 32-cell pro-embryo stage PIN1 protein is localized in the provascular cells facing the basal embryo pole (hypophysis), while PIN7 is localized in the apical side of the suspensor cells facing the pro-embryo (Fig. 1b, c). PIN1 and PIN7 localization reflect early apical-basal polarization and presumably, auxin is transported through the auxin efflux factor (PIN7) to the apical daughter cell of the zygote where it accumulates, and after that the PIN1 proteins play an important role in auxin flux from the globular embryo stage and during the lifespan of the plant (Friml et al. 2003). Abnormalities in the apical daughter cell of the zygote were shown in $A$. thaliana pin 7 mutants where specification was compromised due to its horizontal division instead of vertical cell division.
As a consequence, $\operatorname{pin} 7$ mutants failed to establish the proembryo properly. On the other hand, pinl mutants showed defects at the basal embryo pole compromising the normal development of the hypophysis (Friml et al. 2003). Despite the abnormalities in pro-embryos, pin 1 and $\operatorname{pin} 7$ mutants recovered and produced fertile plants. Probably, the recovery of these mutants is because of functional redundancy among PIN genes. Interestingly, abnormalities are developed in double, triple and quadruple pin mutants to avoid PIN genes functional redundancy, pin 4 pin 7 double mutants showed abnormal cotyledon number, pin1 pin 3 pin 4 triple mutants showed fused cotyledons and the root was very short, and pin 1 pin 3 pin 4 pin 7 quadruple mutants displayed misplaced or fused cotyledons, apical structures absent, nonfunctional root formation, and loss of apical-basal polarity generating ball-shaped embryos. Similar defects were shown in embryos after interfering with auxin homeostasis when they are cultured in artificial conditions using 2,4-D (as an influx substrate) or auxin-efflux inhibitors as NAP (Fig. 1b) (Friml et al. 2003; Palovaara and Hakman 2009).

Another important player involved in the apical-basal polarity in the early embryo is the MAPK (mitogen activated protein kinase) kinase kinase gene YODA (YDA) that leads the (YDA)-signaling pathway (Lukowitz et al. 2004). The $y d a$ mutants show a dwarf phenotype because the loss of function of the YDA gene affects zygote elongation and the normal development of the suspensor (the suspensor cells generally have morphology similar to the pro-embryos cells and the large vacuole characteristic of these cells is lacking). As a result, the apical-basal polarity of the future embryo is disrupted (Lukowitz et al. 2004; Musielak and Bayer 2014). Conversely, YDA gain-of-function alleles promote exaggerated suspensor growth and suppress embryo development (Lukowitz et al. 2004). The MPK3 and MPK6 are other MAPK kinase kinase genes that act redundantly downstream of the $Y D A$ gene in the embryogenic pathway.

The mpk3 mpk6 double mutants displayed the same phenotype of $y d a$ mutants (Musielak and Bayer 2014). It was identified in zygotic embryogenesis that the short suspensor (SSP) and grounded (GRD) genes also act by controlling the YDA-signaling pathway especially the SSP gene that is a member of the interleukin-1 receptor-associated kinase (IRAK)/Pelle-like kinase family of receptors likekinases (Wendrich and Weijers 2013). The SSP protein is a membrane-bound protein that is under the control of pollen cells, which is translated specifically after fertilization and after that, it activates the YDA-signaling pathway in zygotic embryogenesis (Wendrich and Weijers 2013). The protein RKD4 encoded by the $G R D$ gene was identified in somatic embryogenic cultures inducing the embryogenic fate in somatic cells when overexpressed, and it is also expressed in ZE for pattern formation from the first division onward (Fig. 1b) (Waki et al. 2011; Mursyanti et al. 2016). 
Loss-of-function of the $G R D$ gene induces the reduction of the elongation of the zygote and abnormal early cell division. Phenotypically, the $\mathrm{grd} / \mathrm{rkd} 4 \mathrm{mutant}$ looks like the $y d a$ and spp mutants probably because of the interaction of the GRD/RKD4 with the YDA-signaling pathway (Jeong et al. 2011).It was also found that GRD/RKD4 acts in cooperation with WOX8 and WOX9 for establishing embryo polarity (Fig. 1b) (Jeong et al. 2011). In this way, GRD/RKD4 is related to the signaling cascade (mechanism unknown) where YDA, WOX2, WOX8, WOX9 genes and theWRYK2 and PIN proteins are interconnected in synergy for the normal zygotic and SE development (Fig. 1a, b).

\section{Abnormalities in ZE can be used as a model of somatic embryogenesis development}

The use of mutants in zygotic embryogenesis has been an important tool to understand embryo development in their different stages. Investigations in A. thaliana and other species such as Zea mays have increased our understanding of abnormalities in ZE (Clark and Sheridan 1988; Meinke 1995; Vernon and Meinke 1995; Bastida et al. 2006). Abnormalities have been induced by mutation in the DNA sequence of the ZE, generally by chemical and physical mutagenesis or by loss-of-function phenotypes using gene knockout techniques (mainly T-DNA insertion mutagenesis) resulting in embryo-defective (emb) mutants (Meinke 1985; Devic 2008). As a result, embryogenic processes from the emb mutants are disrupted. The mutants do not develop beyond the cotyledonary stage and show morphogenic alterations, anomalous differentiation and problems in the maturation stage. The principal abnormalities found in these emb mutants are lack of pigmentation, disorganized vegetative growth and dwarfism (Clark and Sheridan 1988; Vernon and Meinke 1995). Several emb mutants with interesting defects in embryo development have been described by a wide number of publications (Meinke and Sussex 1979a, b; Meinke 1991, 1995; McElver et al. 2001; Tzafrir 2004; Muralla et al. 2011). In order to collect all the information about $A$. thaliana emb mutants available, a database at http://www.seedgenes.org is accessible. This database includes more than 400 EMBRYO-DEFECTIVE $(E M B)$ genes and 888 mutant alleles, where $1 \%$ is related to defective seeds, $15 \%$ to abnormalities in seed pigmentation and $84 \%$ is related to $e m b$ (747 out of 888 mutant alleles). With this complete information, a classic genetic map has been saturated in order to facilitate the analysis of important genes in A. thaliana embryo development (McElver et al. 2001; Meinke 2003; Meinke et al. 2009).

Plant embryogenesis is a process generally divided in four phases such as embryo development, maturation, desiccation and germination (Apuya et al. 2001). Embryo development and conversion into plant are processes controlled by molecular mechanisms as gene expression, where emb mutants can help in understanding the correlation between phenotypes and gene functions. Vernon and Meinke (1995) reported several representative emb mutants called late embryo defectives in A. thaliana. These mutants develop beyond the globular stage, but cannot become normal plants (Vernon and Meinke 1995; Patton et al. 1998). Representative late embryo mutants were chosen for further morphological analyses (Table 3). Comparing wild-type embryos with mutant embryos it is easier to identify differences in the size and morphologies. Mutant embryos are small and white, but some can develop green cotyledons such as emb266 and emb270. The embryo mutants of emb224, emb232 and emb256-1 developed until the heart stage, but the young cotyledons were malformed, and the hypocotyl was reduced. While emb152, emb163 and emb201 develop until the cotyledonal stage, but the cotyledons were excessively reduced. Conversely, emb163 and emb266 showed multiple cotyledons in rosette shape, which were occasionally observed in emb223 and emb209 (Vernon and Meinke 1995).

Several embryo-lethal mutants were also evaluated to understand the molecular function of some genes in developmental processes from A. thaliana. The emb49 is an embryo mutant in biotin precursors (dethiobiotin) that shows multiple cotyledons deformation and its development is slow compared with wild-type embryos (Patton et al. 1998). Mutants with low expression of the gene Alanyl-tRNA synthetase induce weak pro-embryos and its expression stops along with globular embryo development. Although embryos at the globular stage are aborted, some of them can be germinated by embryo rescue techniques. The resulting seedlings showed short hypocotyl and the shoot meristem twisted (Sun et al. 1998).The schlepperless is a mutant in the chaperonin-60 $\alpha$ gene. Embryo mutants for the chaperonin-60 $\alpha$ gene show normal development but their growth is slow and the development is arrested at the heart stage (Apuya et al. 2001). The T-DNA insertion mutant slow embryo development 1 that affects a protein targeted to mitochondria showed a slower development compared to wild-type embryos. These mutants at the early globular stage are white in appearance. In the maturation stage, production and accumulation of proteins and lipids in their body is poor ( $\mathrm{Ju}$ et al. 2016). The enzyme serine decarboxylase (SDC1), which directly converts serine to ethanolamine, is essential in plant embryogenesis. Mutations in the gene coding for this enzyme can arrest embryo development in A. thaliana. In this study, it was shown that embryo lethal defects are produced with the knockout of the SDC1 gene (Yunus et al. 2016). Another important enzyme for ZE development is the putative glutamate carboxypeptidase encoded by Altered Meristem Program 1 (AMPI) gene. 
Table 3 Several characteristics observed in lethal embryos in the model plant A. thaliana

\begin{tabular}{|c|c|c|}
\hline Mutant/mutation & Characteristic & References \\
\hline emb22 & Arrested embryo at globular stage that failed to produce hypocotyls and cotyledons & Patton and Meinke (1990) \\
\hline emb30 & $\begin{array}{l}\text { Aborted seeds with green embryos with hypocotyls reduced and distorted cotyledons } \\
\text { fused forming a conical structure }\end{array}$ & Patton and Meinke (1990) \\
\hline emb31 & Normal hypocotyls with pale cotyledons that varied in size and morphology & Patton and Meinke (1990) \\
\hline fusca3 & $\begin{array}{l}\text { Dormancy and desiccation tolerance is altered, storage proteins levels reduced and } \\
\text { cotyledons with trichomes }\end{array}$ & Keith et al. (1994) \\
\hline sus & Enlarged suspensor phenotype at maturity stage & Schwartz et al. (1994) \\
\hline fusca & $\begin{array}{l}\text { High levels of anthocyanin accumulation, inhibition of hypocotyls elongation, apical } \\
\text { hook opening, unfolding of cotyledons }\end{array}$ & Mis et al. (1994) \\
\hline emb266 & Dwarfism & Vernon and Meinke (1995) \\
\hline emb270 & Dwarfism & Vernon and Meinke (1995) \\
\hline$e m b 224, e m b 232, e m b 256-1$ & Large heart shape with abnormal cotyledons and reduced hypocotyl & Vernon and Meinke (1995) \\
\hline emb163 & Cotyledons reduced & Vernon and Meinke (1995) \\
\hline emb201 & Cotyledons reduced & Vernon and Meinke (1995) \\
\hline emb223 & Rosette cotyledons malformation & Vernon and Meinke (1995) \\
\hline emb209 & Rosette cotyledons malformation & Vernon and Meinke (1995) \\
\hline Shoot meristemless & Shoot meristem reduced or completely absent in mature embryos & Endrizzi et al. (1996) \\
\hline wus & Fail to properly organize a shoot meristem in the embryo & Laux et al. (1996) \\
\hline emb49 & Cotyledons deformed as rosettes & Patton et al. (1998) \\
\hline Monopteros & Vascular strands formation interference and body axis alteration & Hardtke and Berleth (1998) \\
\hline Alanyl-tRNASynthetase & Weak embryos in globular stage & Sun et al. (1998) \\
\hline emb30 & Abnormal cell wall and deficient polar cell growth control & Shevell et al. (2000) \\
\hline Schlepperless & Retardation of embryo development before the heart stage & Apuya et al. (2001) \\
\hline Topless-1 & Transformation of the shoot pole of the embryo into a root & Long et al. (2002) \\
\hline$h o c$ & Over production of cytokinin, bushy phenotype with supernumerary rosettes & Catterou et al. (2002) \\
\hline Pex10 null mutant & Retarded development and morphological abnormalities & Sparkes (2003) \\
\hline Embryo ball & Cotyledons are absent, the apical region produced leaf-like structures with trichomes & Kristof et al. (2008) \\
\hline bobberl & Arrest at the globular stage of development & Jurkuta et al. (2009) \\
\hline gnom & Root meristem deficient and cotyledon primordial formation fails & Wolters et al. (2011) \\
\hline Dicer-like1 & Early embryo maturation & Willmann et al. (2011) \\
\hline lec1 & Cotyledon identity altered and ectopic trichomes formation & Huang et al. (2015) \\
\hline Slow embryo development 1 & Slower development in globular stage and white appearance & Ju et al. (2016) \\
\hline Serine decarboxylase & Arrest embryo development & Yunus et al. (2016) \\
\hline Altered Meristem Program 1 & Seeds develop deficient coat & López-García et al. (2016) \\
\hline
\end{tabular}

When this enzyme is defective, an increased frequency of embryo abortion occurs because the seeds develop deficiency in coat formation (López-García et al. 2016). Complementary information about other important mutants with gene dysfunction is listed in the Table 3 . The abnormalities presented in embryos-defective mutants have similarities with some SE abnormalities such as cotyledons lacking or malformed, lacking apical and radical meristems, translucent color and loss of bipolarity, among others (Chanatásig 2004; Hashemloian et al. 2008; El Dawayati et al. 2012; Ruffoni and Savona 2013). Reverse genetics can be an interesting methodology to evaluate SE abnormalities using the information about abnormalities in the counterpart ZE mutants with the aim to identify the phenotypes generated by a specific mutation; thus, in this way implement strategies to improve somatic embryogenesis protocols.

\section{Conclusion}

Morphological deformation occurs commonly in SE. These morphological abnormalities are a result of physiological disorders or somaclonal variation. Depending on the genotype, some in vitro culture conditions can improve embryo quality by reducing abnormalities (Table 1). 2,4-D is one of the most important PGR used to induce somatic embryogenesis; high concentration and long exposition to this PGR generates embryo abnormalities (Cruz et al. 1990; Gaj 2004; Vondráková et al. 2011). It is well known that 2,4-D disrupts auxin 
homeostasis in embryos when applied in vitro (Friml et al. 2003; Palovaara and Hakman 2009). Epigenetic and genetic changes are also attributed to the use of 2,4-D because this PGR can induce methylation or mutations in the DNA (LoSchiavo et al. 1989; Leljak-Levanić et al. 2004; Fraga et al. 2012; Fehér 2015). Auxin polar transportation can be compromised with the use of 2,4-D in high concentrations. This PGR affects the right expression of PIN genes (especially PINI) by inducing methylation of the DNA (Xiao 2006; Fraga et al. 2016). Two important PIN proteins are expressed in the embryo patterning (PIN1 and PIN7). Mutation or inactivation of genes that codify these proteins affect the establishment of apicalbasal polarity in the early embryo formation (Tvorogova et al. 2015). Another important protein that is involved in the cell fate and embryo patterning is the WRKY protein. This protein takes part in regulating WOX8 and WOX9 expression in the basal embryo lineage (Ueda et al. 2011; Zhang and Laux 2011). WOX8/9 genes are important players in establishing cell bipolarity because they are activators of WOX2 genes, which in turn, activate PINI expression (Breuninger et al. 2008). WOX2, WOX8 and WOX9 genes are the main actors in embryo polarization. WOX8/9 induce the basal cell division forming the suspensor, while WOX2 induces the apical cell division developing the embryo proper (Breuninger et al. 2008). Along with WOX and PIN genes, LEC, YDA and GRD are related to the morphogenetic network in $\mathrm{ZE}$, and they also play an important role in somatic embryogenesis (Lukowitz et al. 2004; Gaj et al. 2005; Waki et al. 2011; Mursyanti et al. 2016). Abnormal embryo development can be caused by mutation or inactivation of the above-mentioned genes by epigenetic repression when 2,4-D is applied in artificial culture conditions. Several studies in somatic embryogenesis use 2,4-D as the main inducer. It is known that somatic embryogenesis can also be induced by stress treatments with other chemical or physical agents (Fehér 2015). This can be an alternative to reduce the use of 2,4-D to stimulate embryo generation. This potent auxin remains in the tissue for a long period and is difficult to remove. Abnormal embryo development can occur because of this accumulation.

Mutations in ZE can help us to understand which genes are involved in the embryo morphogenesis (Table 3). Several abnormalities displayed in $e m b$ mutants are similar to those produced in SE. The application of reverse genetics in somatic embryogenesis using the broad information available about emb mutants allows us to identify the cause of the abnormalities. Some abnormalities in $e m b$ mutants are produced by disruption of metabolic pathways where a protein or precursor is defective. The comprehension of this biochemical information enables us to create strategies to manipulate culture conditions for improving specific somatic embryogenesis protocols.
Author contributions A-AA and MC conceived the review. CG wrote the manuscript. RV, DB and SR conducted English revision. J-PM contribute with the current funding sources. All the authors read and approved the manuscript.

\section{Compliance with ethical standards}

Conflict of interest The authors declare that they have no competing interests.

Open Access This article is distributed under the terms of the Creative Commons Attribution 4.0 International License (http://creativeco mmons.org/licenses/by/4.0/), which permits unrestricted use, distribution, and reproduction in any medium, provided you give appropriate credit to the original author(s) and the source, provide a link to the Creative Commons license, and indicate if changes were made.

\section{References}

Abrahamsson M, Valladares S, Larsson E et al (2012) Patterning during somatic embryogenesis in Scots pine in relation to polar auxin transport and programmed cell death. Plant Cell Tissue Organ Cult PCTOC 109:391-400. https://doi.org/10.1007/s1124 0-011-0103-8

Ammirato PV (1974) The effects of abscisic acid on the development of somatic embryos from cells of caraway (Carum carvi L.). Bot Gaz 135:328-337. https://doi.org/10.1086/336769

Apuya NR, Yadegari R, Fischer RL et al (2001) The Arabidopsis embryo mutant schlepperless has a defect in the chaperonin-60 $\alpha$ gene. Plant Physiol 126:717-730

Ascencio-Cabral A, Gutiérrez-Pulido H, Rodríguez-Garay B, Gutiérrez-Mora A (2008) Plant regeneration of Carica papaya L. through somatic embryogenesis in response to light quality, gelling agent and phloridzin. Sci Hortic 118:155-160. https://doi. org/10.1016/j.scienta.2008.06.014

Aydin M, Arslan E, Taspinar MS et al (2016) Analyses of somaclonal variation in endosperm-supported mature embryo culture of rye (Secale cereale L.). Biotechnol Biotechnol Equip. https://doi. org/10.1080/13102818.2016.1224980

Bahmankar M, Mortazavian SMM, Tohidfar M et al (2017) Chemical compositions, somatic embryogenesis, and somaclonal variation in cumin. BioMed Res Int 2017:1-15. https://doi. org/10.1155/2017/7283806

Bastida M, Graziano E, Roca R et al (2006) A maize defective-kernel mutant (longcell) characterized by tubular cells, severe morphological alterations and induction of cell death. Planta 223:755768. https://doi.org/10.1007/s00425-005-0136-5

Bobadilla Landey R, Cenci A, Guyot R et al (2015) Assessment of genetic and epigenetic changes during cell culture ageing and relations with somaclonal variation in Coffea arabica. Plant Cell Tissue Organ Cult PCTOC 122:517-531. https://doi.org/10.1007/ s11240-015-0772-9

Bouchabké-Coussa O, Obellianne M, Linderme D et al (2013) Wuschel overexpression promotes somatic embryogenesis and induces organogenesis in cotton (Gossypium hirsutum L.) tissues cultured in vitro. Plant Cell Rep 32:675-686. https://doi.org/10.1007/ s00299-013-1402-9

Breuninger H, Rikirsch E, Hermann M et al (2008) Differential expression of WOX genes mediates apical-basal axis formation in the Arabidopsis embryo. Dev Cell 14:867-876. https://doi. org/10.1016/j.devcel.2008.03.008

Catterou M, Dubois F, Smets R et al (2002) hoc: an Arabidopsis mutant overproducing cytokinins and expressing high 
in vitro organogenic capacity. Plant J 30:273-287. https://doi. org/10.1046/j.1365-313X.2002.01286.x

Chakrabarty D, Yu KW, Paek KY (2003) Detection of DNA methylation changes during somatic embryogenesis of Siberian ginseng (Eleuterococcus senticosus). Plant Sci 165:61-68. https://doi. org/10.1016/S0168-9452(03)00127-4

Chanatásig CI (2004) Inducción de la embriogénesis somática en clones superiores de cacao (Theobroma cacao L.), con resistencia a enfermedades fungosas. CATIE 1-86. Retrieved from http:// orton.catie.ac.cr/repdoc/A0275e/A0275e.pdf

Chée RP, Cantliffe DJ (1989) Inhibition of somatic embryogenesis in response to 2, 3, 5-triiodobenzoic acid and 2, 4-dichlorophenoxyacetic acid in Ipomoea batatas (L.) Lam. cultured in vitro. J Plant Physiol 135:398-403

Chen JT, Chang WC (2000) Plant regeneration via embryo and shoot bud formation from flower-stalk explants of Oncidium Sweet Sugar. Plant Cell Tissue Organ Cult 62:95-100

Chen J-R, Wu L, Hu B-W et al (2014) The influence of plant growth regulators and light quality on somatic embryogenesis in China Rose (Rosa chinensis Jacq.). J Plant Growth Regul 33:295-304. https://doi.org/10.1007/s00344-013-9371-3

Cho D-Y, Lee E-K, Lee S et al (2003) Enhanced somatic embryogenesis and plant regeneration in leaf explant cultures of Ostericum koreanum on medium of varying $\mathrm{pH}$. Plant Cell Tissue Organ Cult 75:215-222

Cipriano JLD, Cruz ACF, Mancini KC et al (2018) Somatic embryogenesis in Carica papaya as affected by auxins and explants, and morphoanatomical-related aspects. An Acad Bras Ciênc 90:385-400. https://doi.org/10.1590/0001-3765201820160252

Clark JK, Sheridan WF (1988) Characterization of the two maize embryo-lethal defective kernel mutants $r g h^{*}-1210$ and $f *^{*}$ 1253b: effects on embryo and gametophyte development. Genetics 120:279-290

Corredoira E, Valladares S, Vieitez AM (2006) Morphohistological analysis of the origin and development of somatic embryos from leaves of mature Quercus robur. Vitro Cell Dev BiolPlant 42:525-533. https://doi.org/10.1079/IVP2006827

Cruz GS, Canhoto JM, Abreu MAV (1990) Somatic embryogenesis and plant regeneration from zygotic embryos of Feijoa sellowiana Berg. Plant Sci 66:263-270

Daniel MA, David RHA, Caesar SA et al (2018) Effect of 1 -glutamine and casein hydrolysate in the development of somatic embryos from cotyledonary leaf explants in okra (Abelmoschus esculentus L. monech). South Afr J Bot 114:223-231. https:// doi.org/10.1016/j.sajb.2017.11.014

De-la-Peña C, Nic-Can G, Ojeda G et al (2012) KNOX1 is expressed and epigenetically regulated during in vitro conditions in Agave spp. BMC Plant Biol 12:1-11

De-la-Peña C, Nic-Can GI, Galaz-Ávalos RM et al (2015) The role of chromatin modifications in somatic embryogenesis in plants. Front Plant Sci 6:1-16. https://doi.org/10.3389/ fpls.2015.00635

Devic M (2008) The importance of being essential: EMBRYODEFECTIVE genes in Arabidopsis. C R Biol 331:726-736. https://doi.org/10.1016/j.crvi.2008.07.014

Dey T, Saha S, Ghosh PD (2015) Somaclonal variation among somatic embryo derived plants-evaluation of agronomically important somaclones and detection of genetic changes by RAPD in Cymbopogon winterianus. South Afr J Bot 96:112121. https://doi.org/10.1016/j.sajb.2014.10.010

Dodeman VL, Ducreux G, Kreis M (1997) Zygotic embryogenesis versus somatic embryogenesis. J Exp Bot 48:1493-1509

Duarte-Aké F, Castillo-Castro E, Pool FB et al (2016) Physiological differences and changes in global DNA methylation levels in Agave angustifolia Haw. albino variant somaclones during the micropropagation process. Plant Cell Rep 35:2489-2502. https ://doi.org/10.1007/s00299-016-2049-0

El Dawayati MM, Abd EL, Bar OH, Zaid ZE, Zein El Din AFM (2012) In vitro morpho-histological studies of newly developed embryos from abnormal malformed embryos of date palm cv. Gundila under desiccation effect of polyethelyne glycol treatments. Ann Agric Sci 57:117-128. https://doi.org/10.1016/j. aoas.2012.08.005

Endrizzi K, Moussian B, Haecker A et al (1996) The SHOOT MERISTEMLESS gene is required for maintenance of undifferentiated cells in Arabidopsis shoot and floral meristems and acts at a different regulatory level than the meristem genes WUSCHEL. and ZWILLE. Plant J 10:967-979

Etienne H, Bertrand B (2003) Somaclonal variation in Coffea arabica: effects of genotype and embryogenic cell suspension age on frequency and phenotype of variants. Tree Physiol 23:419-426

Eulgem T, Rushton PJ, Robatzek S, Somssich IE (2000) The WRKY superfamily of plant transcription factors. Trends Plant Sci 5:199-206

Fehér A (2015) Somatic embryogenesis—-stress-induced remodeling of plant cell fate. Biochim Biophys Acta BBA-Gene Regul Mech 1849:385-402. https://doi.org/10.1016/j.bbagrm.2014.07.005

Fehér A, Pasternak T, Dudits D (2003) Transition of somatic plant cells to an embryogenic state. Plant Cell Tissue Organ Cult 74:201-228

Fernando JA, Melo M, Soares MK, Appezzato-da-Glória B (2001) Anatomy of somatic embryogenesis in Carica papaya L. Braz Arch Biol Technol 44:247-255

Finnegan EJ, Peacock WJ, Dennis ES (2000) DNA methylation, a key regulator of plant development and other processes. Curr Opin Genet Dev 10:217-223

Fraga HPF, Vieira LN, Caprestano CA et al (2012) 5-Azacytidine combined with 2,4-D improves somatic embryogenesis of Acca sellowiana (O. Berg) Burret by means of changes in global DNA methylation levels. Plant Cell Rep 31:2165-2176. https://doi. org/10.1007/s00299-012-1327-8

Fraga HPF, Vieira LN, Heringer AS et al (2016) DNA methylation and proteome profiles of Araucaria angustifolia (Bertol.) Kuntze embryogenic cultures as affected by plant growth regulators supplementation. Plant Cell Tissue Organ Cult PCTOC 125:353374. https://doi.org/10.1007/s11240-016-0956-y

Francischini JHMB, Kemper EL, Costa JB et al (2017) DNA methylation in sugarcane somaclonal variants assessed through methylation-sensitive amplified polymorphism. Genet Mol Res 16:1-12. https://doi.org/10.4238/gmr16029585

Friml J, Vieten A, Sauer M et al (2003) Efflux-dependent auxin gradients establish the apical-basal axis of Arabidopsis. Nature 426:147-153

Gaj M (2004) Factors influencing somatic embryogenesis induction and plant regeneration with particular reference to Arabidopsis thaliana (L.) Heynh. Plant Growth Regul 43:27-47

Gaj MD, Zhang S, Harada JJ, Lemaux PG (2005) Leafy cotyledon genes are essential for induction of somatic embryogenesis of Arabidopsis. Planta 222:977-988. https://doi.org/10.1007/s0042 5-005-0041-y

Garcia C, Corrêa F, Findley S et al (2016) Optimization of somatic embryogenesis procedure for commercial clones of Theobroma cacao L. Afr J Biotechnol 15:1936-1951. https://doi. org/10.5897/AJB2016.15513

Germana MA, Lambardi M (2016) In vitro embryogenesis in higher plants. Methods Mol Biol 1359:1-577

Ghosh A, Igamberdiev AU, Debnath SC (2017) Detection of DNA methylation pattern in thidiazuron-induced blueberry callus using methylation-sensitive amplification polymorphism. Biol Plant 61:511-519 
Goyali JC, Igamberdiev AU, Debnath SC (2018) DNA methylation in lowbush blueberry (Vaccinium angustifolium Ait.) propagated by softwood cutting and tissue culture. Can J Plant Sci 1-35

Gray DJ, McColley DW, Compton ME (1993) High-frequency somatic embryogenesis from quiescent seed cotyledons of Cucumis melo cultivars. J Am Soc Hortic Sci 118:425-432

Guillou C, Fillodeau A, Brulard E et al (2018) Indirect somatic embryogenesis of Theobroma cacao L. in liquid medium and improvement of embryo-to-plantlet conversion rate. Vitro Cell Dev Biol - Plant 54:377-391. https://doi.org/10.1007/s11627-018-9909-y

Guo F, Liu C, Xia H et al (2013) Induced expression of AtLEC1 and AtLEC2 differentially promotes somatic embryogenesis in transgenic tobacco plants. PLoS ONE 8:1-7. https://doi.org/10.1371/ journal.pone.0071714

Gutmann M, von Aderkas P, Label P, Lelu M-A (1996) Effects of abscisic acid on somatic embryo maturation of hybrid larch. J Exp Bot 47:1905-1917. https://doi.org/10.1093/jxb/47.12.1905

Haecker A (2004) Expression dynamics of WOX genes mark cell fate decisions during early embryonic patterning in Arabidopsis thaliana. Development 131:657-668. https://doi.org/10.1242/ dev.00963

Harada J (2001) Role of Arabidopsis LEAFY COTYLEDON genes in seed development. Plant Physiol 158:405-409

Hardtke CS, Berleth T (1998) The Arabidopsis gene MONOPTEROS encodes a transcription factor mediating embryo axis formation and vascular development. EMBO J 17:1405-1411

Hashemloian BD, Ataei-Azimi A, Majd A, Ebrahimzadeh H (2008) Abnormal plantlets regeneration through direct somatic embryogenesis on immature seeds of Vinca herbacea Waldst. and Kit. Afr J Biotechnol 7:1679-1683

Hazubska-Przybył T, Dering M (2017) Somaclonal variation during Picea abies and P. omorika somatic embryogenesis and cryopreservation. Acta Biol Cracoviensia Bot 59:93-103. https://doi. org/10.1515/abcsb-2017-0003

Heinz DJ, Mee GWP (1971) Morphologic, cytogenetic, and enzymatic variation in Saccharum species hybrid clones derived from callus tissue. Am J Bot 58:257-262. https://doi.org/10.2307/2441162

Hitomi A, Amagai H, Ezura H (1998) The influence of auxin type on the array of somaclonal variants generated from somatic embryogenesis of eggplant, Solanum melongena L. Plant Breed 117:379-383

Homhuan S, Kijwijan B, Wangsomnuk P et al (2008) Variation of plants derived from indirect somatic embryogenesis in cotyledon explants of papaya. Sci Asia 34:347-352

Horstman A, Bemer M, Boutilier K (2017) A transcriptional view on somatic embryogenesis. Regeneration 4:201-216. https://doi. org/10.1002/reg2.91

Huang M, Hu Y, Liu X et al (2015) Arabidopsis LEAFY COTYLE$D O N 1$ controls cell fate determination during post-embryonic development. Front Plant Sci 6:1-8. https://doi.org/10.3389/ fpls.2015.00955

Isabel N, Boivin R, Levasseur C et al (1996) Occurrence of somaclonal variation among somatic embryo-derived white spruces (Picea glauca, Pinaceae). Am J Bot 83:1121-1130. https://doi. org/10.2307/2446195

Issa J-PJ, Kantarjian HM (2009) Targeting DNA methylation. Clin Cancer Res 15:3938-3946. https://doi.org/10.1158/1078-0432. CCR-08-2783

Jain SM, Brar DS, Ahloowalia BS, Summerfield RJ (1998) Somaclonal variation and induced mutations in crop improvement. Curr Plant Sci Biotechnol Agric 32:1-619. https://doi. org/10.1007/978-94-015-9125-6

Jalali MA, Sirmandi HB, Hatamzadeh A (2017) Effects of carbohydrate source and polyethylene glycol on maturation and germination of somatic embryos in walnut (Juglans regia L.). J Crop Sci Biotechnol 20:29-35

Jeong S, Palmer TM, Lukowitz W (2011) The $R W P-R K$ Factor GROUNDED promotes embryonic polarity by facilitating YODA MAP kinase signaling. Curr Biol 21:1268-1276. https://doi. org/10.1016/j.cub.2011.06.049

Ji W, Luo Y, Guo R et al (2017) Abnormal somatic embryo reduction and recycling in grapevine regeneration. J Plant Growth Regul. https://doi.org/10.1007/s00344-017-9694-6

Joshi M, Sujatha K, Hazra S (2008) Effect of TDZ and 2, 4-D on peanut somatic embryogenesis and in vitro bud development. Plant Cell Tissue Organ Cult 94:85-90. https://doi.org/10.1007/ s11240-008-9390-0

Ju Y, Liu C, Lu W et al (2016) Arabidopsis mitochondrial protein slow embryo development 1 is essential for embryo development. Biochem Biophys Res Commun 474:371-376. https://doi. org/10.1016/j.bbrc.2016.04.114

Jurkuta RJ, Kaplinsky NJ, Spindel JE, Barton MK (2009) Partitioning the apical domain of the Arabidopsis embryo requires the BOBBER1 NudC domain protein. Plant Cell Online 21:1957-1971. https://doi.org/10.1105/tpc.108.065284

Keith K, Kraml M, Dengler NG, McCourt P (1994) Fusca3: a heterochronic mutation affecting late embryo development in Arabidopsis. Plant Cell 6:589-600

Kim S, Kaang B-K (2017) Epigenetic regulation and chromatin remodeling in learning and memory. Exp Mol Med 49:e281-e281. https ://doi.org/10.1038/emm.2016.140

Kitimu SR, Taylor J, March TJ et al (2015) Meristem micropropagation of cassava (Manihot esculenta) evokes genome-wide changes in DNA methylation. Front Plant Sci 6:1-12. https://doi. org/10.3389/fpls.2015.00590

Kondo H, Ozaki H, Itoh K et al (2006) Flowering induced by 5-azacytidine, a DNA demethylating reagent in a short-day plant, Perilla frutescens var. crispa. Physiol Plant 127:130-137. https://doi.org /10.1111/j.1399-3054.2005.00635.x

Körbes AP, Droste A (2005) Carbon sources and polyethylene glycol on soybean somatic embryo conversion. Pesqui Agropecuária Bras 40:211-216

Krishna H, Alizadeh M, Singh D et al (2016) Somaclonal variations and their applications in horticultural crops improvement. 3 Biotech 6:1-18. https://doi.org/10.1007/s13205-016-0389-7

Kristof JR, Coppersmith L, Hong J K, et al (2008) An Arabidopsis thaliana embryo arrest mutant exhibiting germination potential. Seed Sci Res 18:55-65. https://doi.org/10.1017/S0960258508974377

Kumar V, Van Staden J (2017) New insights into plant somatic embryogenesis: an epigenetic view. Acta Physiol Plant 39:1-17. https:// doi.org/10.1007/s11738-017-2487-5

Landey RB, Cenci A, Georget F et al (2013) High genetic and epigenetic stability in Coffea arabica plants derived from embryogenic suspensions and secondary embryogenesis as revealed by AFLP, MSAP and the phenotypic variation rate. PLoS ONE 8:1-15

Larkin P, Scowcroft W (1981) Somaclonal variation-a novel source of variability from cell cultures for plant improvement. Theor Appl Genet 60:197-214

Larsson E, Sitbon F, Ljung K, von Arnold S (2007) Inhibited polar auxin transport results in aberrant embryo development in Norway spruce. New Phytol 177:356-366. https://doi.org/10.111 1/j.1469-8137.2007.02289.x

Laux T (2004) Genetic regulation of embryonic pattern formation. Plant Cell Online 16:S190-S202. https://doi.org/10.1105/ tpc.016014

Laux T, Mayer KFX, Berger J, Jürgens G (1996) The WUSCHEL gene is required for shoot and floral meristem integrity in Arabidopsis. Development 122:87-96 
Lazzeri PA, Hildebrand DF, Collins GB (1987) Soybean somatic embryogenesis: effects of nutritional, physical and chemical factors. Plant Cell Tissue Organ Cult 10:209-220

Ledwoń A, Gaj MD (2009) LEAFY COTYLEDON2 gene expression and auxin treatment in relation to embryogenic capacity of Arabidopsis somatic cells. Plant Cell Rep 28:1677-1688. https://doi. org/10.1007/s00299-009-0767-2

Leljak-Levanić D, Bauer N, Mihaljević S, Jelaska S (2004) Changes in DNA methylation during somatic embryogenesis in Cucurbita pepo L. Plant Cell Rep 23:120-127. https://doi.org/10.1007/ s00299-004-0819-6

Lelu-Walter M-A, Gautier F, Eliášová K et al (2018) High gellan gum concentration and secondary somatic embryogenesis: two key factors to improve somatic embryo development in Pseudotsuga menziesii [Mirb.]. Plant Cell Tissue Organ Cult PCTOC 132:137-155. https://doi.org/10.1007/s11240-017-1318-0

Liu CM, Xu ZH, Chua N-H (1993) Auxin polar transport is essential for the establishment of bilateral symmetry during early plant embryogenesis. Plant Cell 5:621-630

Lloyd CW, Lowe SB, Peace GW (1980) The mode of action of 2,4-D in counter-acting the elongation of carrot cells grown in culture. J Cell Sci 45:257-268

Long JA, Woody S, Poethig S et al (2002) Transformation of shoots into roots in Arabidopsis embryos mutant at the TOPLESS locus. Development 129:2297-2306

López-García CM, Raya-González J, López-Bucio JS et al (2016) ALTERED MERISTEM PROGRAM 1 plays a role in seed coat development, root growth, and post-embryonic epidermal cell elongation in Arabidopsis. J Plant Growth Regul 35:1141-1158. https://doi.org/10.1007/s00344-016-9612-3

Lopez-Puc G, Canto-Flick A, Barredo-Pool F et al (2006) Direct somatic embryogenesis: A highly efficient protocol for in vitro regeneration of habanero pepper (Capsicum chinense Jacq.). HortScience 41:1645-1650

LoSchiavo F, Pitto L, Giuliano G et al (1989) DNA methylation of embryogenic carrot cell cultures and its variations as caused by mutation, differentiation, hormones and hypomethylating drugs. Theor Appl Genet 77:325-331

Lukowitz W, Roeder A, Parmenter D, Somerville C (2004) A MAPKK kinase gene regulates extra-embryonic cell fate in Arabidopsis. Cell 116:109-119

Maximova SN, Alemanno L, Young A et al (2002) Efficiency, genotypic variability, and cellular origin of primary and secondary somatic embryogenesis of Theobroma cacao L. Vitro Cell Dev Biol-Plant 38:252-259. https://doi.org/10.1079/IVP2001257

Mazri MA, Meziani R, Belkoura I et al (2018) A combined pathway of organogenesis and somatic embryogenesis for an efficient large-scale propagation in date palm (Phoenix dactylifera $\mathrm{L}$.) cv. Mejhoul 3 Biotech 8:1-8. https://doi.org/10.1007/s1320 5-018-1235-x

McElver J, Tzafrir I, Aux G et al (2001) Insertional mutagenesis of genes required for seed development in Arabidopsis thaliana. Genet Soc Am 159:1751-1763

Meinke DW (1985) Embryo-lethal mutants of Arabidopsis thaliana: analysis of mutants with a wide range of lethal phases. Theor Appl Genet 69:543-552

Meinke DW (1991) Embryonic mutants of Arabidopsis thaliana. Dev Genet 12:382-392

Meinke DW (1995) Molecular genetics of plant embryogenesis. Annu Rev Plant Biol 46:369-394

Meinke DW (2003) A sequence-based map of Arabidopsis genes with mutant phenotypes. Plant Physiol 131:409-418. https://doi. org/10.1104/pp.014134

Meinke DW, Sussex IM (1979a) Embryo-lethal mutants of Arabidopsis thaliana: a model system for genetic analysis of plant embryo development. Dev Biol 72:50-61
Meinke DW, Sussex IM (1979b) Isolation and characterization of six embryo-lethal mutants of Arabidopsis thaliana. Dev Biol 72:62-72

Meinke D, Sweeney C, Muralla R (2009) Integrating the genetic and physical maps of Arabidopsis thaliana: identification of mapped alleles of cloned essential (EMB) Genes. PLoS ONE 4:1-11. https://doi.org/10.1371/journal.pone.0007386

Michler CH, Lineberger RD (1987) Effects of light on somatic embryo development and abscisic levels in carrot suspension cultures. Plant Cell Tissue Organ Cult 11:189-207

Mis S, Weiland-Heidecker U, Jiirgens G (1994) The FUSCA genes of Arabidopsis: negative regulators of light responses. Mol Gen Genet 244:242-252

Morcillo F, Gagneur C, Adam H et al (2006) Somaclonal variation in micropropagated oil palm. Characterization of two novel genes with enhanced expression in epigenetically abnormal cell lines and in response to auxin. Tree Physiol 26:585-594

Muralla R, Lloyd J, Meinke D (2011) Molecular foundations of reproductive lethality in Arabidopsis thaliana. PLoS ONE 6:1-11. https://doi.org/10.1371/journal.pone.0028398

Mursyanti E, Purwantoro A, Moeljopawiro S, Semiarti E (2016) Induction of somatic embryogenesis through overexpression of ATRKD4 genes in Phalaenopsis "Sogo Vivien". Indones J Biotechnol 20:42-53. https://doi.org/10.22146/ijbiotech.15276

Musielak TJ, Bayer M (2014) YODA signalling in the early Arabidopsis embryo. Biochem Soc Trans 42:408-413

Nic-Can GI, López-Torres A, Barredo-Pool F et al (2013) New insights into somatic embryogenesis: LEAFY COTYLEDON1, $B A B Y$ BOOM1 and WUSCHEL-RELATED HOMEOBOX4 are epigenetically regulated in Coffea canephora. PLoS ONE 8:1-14. https://doi.org/10.1371/journal.pone.0072160

Nissen P, Minocha SC (1993) Inhibition by 2,4-D of somatic embryogenesis in carrot as explored by its reversal by difluoromethylornithine. Physiol Plant 89:673-680. https://doi. org/10.1111/j.1399-3054.1993.tb05272.x

Palovaara J, Hakman I (2009) WOX2 and polar auxin transport during spruce embryo pattern formation. Plant Signal Behav 4:153-155. https://doi.org/10.4161/psb.4.2.7684

Pasternak TP (2002) The role of auxin, $\mathrm{pH}$, and stress in the activation of embryogenic cell division in leaf protoplast-derived cells of alfalfa. Plant Physiol 129:1807-1819. https://doi. org/10.1104/pp.000810

Patton DA, Meinke DW (1990) Ultrastructure of arrested embryos from lethal mutants of Arabidopsis thaliana. Am J Bot 77:653661. https://doi.org/10.2307/2444811

Patton DA, Schetter AL, Franzmann LH et al (1998) An embryodefective mutant of Arabidopsis disrupted in the final step of biotin synthesis. Plant Physiol 116:935-946

Pescador R, Kerbauy GB, Viviani D, Kraus JE (2008) Anomalous somatic embryos in Acca sellowiana (O. Berg) Burret (Myrtaceae). Braz J Bot 31:155-164

Peyvandi M (2010) Somaclonal variation among somatic-embryo derived plants of Olea europaea L “cv. Kroneiki” J Sci Islam Repub Iran 21:7-14

Pinto G, Santos C, Neves L, Araújo C (2002) Somatic embryogenesis and plant regeneration in Eucalyptus globulus Labill. Plant Cell Rep 21:208-213. https://doi.org/10.1007/s00299-002-0505-5

Puigderrajols P (2001) Ultrastructure of early secondary embryogenesis by multicellular and unicellular pathways in cork oak (Quercus suber L.). Ann Bot 87:179-189. https://doi. org/10.1006/anbo.2000.1317

Raghavan V (2004) Role of 2, 4-dichlorophenoxyacetic acid (2, 4-D) in somatic embryogenesis on cultured zygotic embryos of Arabidopsis: cell expansion, cell cycling, and morphogenesis during continuous exposure of embryos to 2, 4-D. Am J Bot 91:1743-1756 
Rathore JS, Rai MK, Shekhawat NS (2012) Induction of somatic embryogenesis in gum arabic tree [Acacia senegal (L.) Willd.]. Physiol Mol Biol Plants 18:387-392. https://doi.org/10.1007/ s12298-012-0130-x

Reyes-Díaz JI, Arzate-Fernández AM, Piña-Escutia JL, VázquezGarcía LM (2017) Media culture factors affecting somatic embryogenesis in Agave angustifolia Haw. Ind Crops Prod 108:81-85. https://doi.org/10.1016/j.indcrop.2017.06.021

Rodríguez Lopez CM, Wetten AC, Wilkinson MJ (2004) Detection and quantification of in vitro-culture induced chimerism using simple sequence repeat (SSR) analysis in Theobroma cacao (L.). Theor Appl Genet 110:157-166. https://doi.org/10.1007/ s00122-004-1823-5

Rodríguez López CM, Bravo HS, Wetten AC, Wilkinson MJ (2010a) Detection of somaclonal variation during cocoa somatic embryogenesis characterised using cleaved amplified polymorphic sequence and the new freeware Artbio. Mol Breed 25:501-516. https://doi.org/10.1007/s11032-009-9348-x

Rodríguez López CM, Wetten AC, Wilkinson MJ (2010b) Progressive erosion of genetic and epigenetic variation in callus-derived cocoa (Theobroma cacao) plants. New Phytol 186:856-868. https://doi.org/10.1111/j.1469-8137.2010.03242 . $\mathrm{x}$

Ruffoni B, Savona M (2013) Physiological and biochemical analysis of growth abnormalities associated with plant tissue culture. Hortic Environ Biotechnol 54:191-205. https://doi. org/10.1007/s13580-013-0009-y

Ruiz ML, Rueda J, Peláez MI et al (1992) Somatic embryogenesis, plant regeneration and somaclonal variation in barley. Plant Cell Tissue Organ Cult 28:97-101

Santos D, Fevereiro P (2002) Loss of DNA methylation affects somatic embryogenesis in Medicago truncatula. Plant Cell Tissue Organ Cult 70:155-161

Schwartz BW, Yeung EC, Meinke DW (1994) Disruption of morphogenesis and transformation of the suspensor in abnormal suspensor mutants of Arabidopsis. Development 120:3235-3245

Shevell DE, Kunkel T, Chua N-H (2000) Cell wall alterations in the Arabidopsis emb30 mutant. Plant Cell 12:2047-2059

Shoemaker RC, Amberger LA, Palmer RG et al (1991) Effect of 2, 4-dichlorophenoxyacetic acid concentration on somatic embryogenesis and heritable variation in soybean [Glycine max (L) Merr.]. Vitro Cell Dev Biol-Plant 27:84-88

Smertenko A, Bozhkov PV (2014) Somatic embryogenesis: life and death processes during apical-basal patterning. J Exp Bot 65:1343-1360. https://doi.org/10.1093/jxb/eru005

Sparkes IA (2003) An Arabidopsis pex10 null mutant is embryo lethal, implicating peroxisomes in an essential role during plant embryogenesis. Plant Physiol 133:1809-1819. https://doi.org/10.1104/ pp.103.031252

Stasolla C (2003) The effects of polyethylene glycol on gene expression of developing white spruce somatic embryos. Plant Physiol 131:49-60. https://doi.org/10.1104/pp.015214

Steinmacher DA, Krohn NG, Dantas ACM et al (2007) Somatic embryogenesis in peach palm using the thin cell layer technique: induction, morpho-histological aspects and AFLP analysis of somaclonal variation. Ann Bot 100:699-709. https://doi.org/10.1093/ aob/mcm 153

Stone SL, Kwong LW, Yee KM et al (2001) LEAFY COTYLEDON2 encodes a B3 domain transcription factor that induces embryo development. Proc Natl Acad Sci 98:11806-11811

Stone SL, Braybrook SA, Paula SL et al (2008) Arabidopsis LEAFY COTYLEDON2 induces maturation traits and auxin activity: implications for somatic embryogenesis. Proc Natl Acad Sci 105:3151-3156

Stuart DA, McCall CM (1992) Induction of somatic embryogenesis using side chain and ring modified forms of phenoxy acid growth regulators. Plant Physiol 99:111-118. https://doi.org/10.1104/ pp.99.1.111

Su YH, Zhao XY, Liu YB et al (2009) Auxin-induced WUS expression is essential for embryonic stem cell renewal during somatic embryogenesis in Arabidopsis. Plant J 59:448-460. https://doi. org/10.1111/j.1365-313X.2009.03880.x

Sun JG, Yao XL, Yang ZX, Zhu ZP (1998) An Arabidopsis embryonic lethal mutant with reduced expression of alanyl-tRNA synthetase gene. Cell Res 8:119-134

Suprasanna P, Desai NS, Sapna G, Bapat VA (2007) Monitoring genetic fidelity in plants derived through direct somatic embryogenesis in sugarcane by RAPD analysis. J N Seeds 8:1-9. https:// doi.org/10.1300/J153v08n03_01

Tchorbadjieva M, Pantchev I (2004) DNA methylation and somatic embryogenesis of orchardgrass (Dactylis glomerata L.). Bulg J Plant Physiol 30:3-13

Tokuji Y, Masuda H (1996) Duration of treatment of carrot hypocotyl explants with 2,4-Dichlorophenoxyacetic acid for direct somatic embryogenesis. Biosci Biotechnol Biochem 60:891-892. https:// doi.org/10.1271/bbb.60.891

Tremblay L, Levasseur C, Tremblay FM (1999) Frequency of somaclonal variation in plants of black spruce (Picea mariana, Pinaceae) and white spruce (P. glauca, Pinaceae) derived from somatic embryogenesis and identification of some factors involved in genetic instability. Am J Bot 86:1373-1381

Tvorogova VE, Lebedeva MA, Lutova LA (2015) Expression of WOX and PIN genes during somatic and zygotic embryogenesis in Medicago truncatula. Russ J Genet 51:1189-1198. https ://doi.org/10.1134/S1022795415120121

Tzafrir I (2004) Identification of genes required for embryo development in Arabidopsis. Plant Physiol 135:1206-1220. https://doi. org/10.1104/pp.104.045179

Ueda M, Zhang Z, Laux T (2011) Transcriptional activation of Arabidopsis axis patterning genes WOX8/9 Links zygote polarity to embryo development. Dev Cell 20:264-270. https://doi. org/10.1016/j.devcel.2011.01.009

Us-Camas R, Rivera-Solís G, Duarte-Aké F, De-la-Peña C (2014) In vitro culture: an epigenetic challenge for plants. Plant Cell Tissue Organ Cult PCTOC 118:187-201. https://doi. org/10.1007/s11240-014-0482-8

Vahedi M, Kalantari S, Alireza Salami S (2015) Effects of osmolytic agents on somatic embryogenesis of saffron (Crocus sativus L.). Not Sci Biol 7:2067-3264. https://doi.org/10.15835/ nsb.7.1.9442

Venkatesh K, Rani AR, Baburao N, Padmaja G (2009) Effect of auxins and auxin polar transport inhibitor (TIBA) on somatic embryogenesis in groundnut (Arachis hypogaea L.). Afr J Plant Sci 3:277-282

Verma SK, Das AK, Gantait S et al (2018) Influence of auxin and its polar transport inhibitor on the development of somatic embryos in Digitalis trojana. 3 Biotech 8:1-8. https://doi.org/10.1007/ s13205-018-1119-0

Vernon DM, Meinke DW (1995) Late embryo-defective mutants of Arabidopsis. genesis 16:311-320

Viehmannova I, Bortlova Z, Vitamvas J et al (2014) Assessment of somaclonal variation in somatic embryo-derived plants of yacon [Smallanthus sonchifolius (Poepp. and Endl.) H. Robinson] using inter simple sequence repeat analysis and flow cytometry. Electron J Biotechnol 17:102-106. https://doi.org/10.1016/j. ejbt.2013.12.011

Vila S, Gonzalez A, Rey H, Mroginski L (2010) Effect of morphological heterogeneity of somatic embryos of Melia azedarach on conversion into plants. Biocell 34:7-13

Vondráková Z, Eliášová K, Fischerová L, Vágner M (2011) The role of auxins in somatic embryogenesis of Abies alba. Open Life Sci 6:587-596. https://doi.org/10.2478/s11535-011-0035-7 
Waki T, Hiki T, Watanabe R et al (2011) The Arabidopsis RWP-RK protein RKD4 triggers gene expression and pattern formation in early embryogenesis. Curr Biol 21:1277-1281. https://doi. org/10.1016/j.cub.2011.07.001

Wendrich JR, Weijers D (2013) The Arabidopsis embryo as a miniature morphogenesis model. New Phytol 199:14-25. https://doi. org/10.1111/nph.12267

West MA, Yee KM, Danao J et al (1994) LEAFY COTYLEDON1 is an essential regulator of late embryogenesis and cotyledon identity in Arabidopsis. Plant Cell 6:1731-1745

Willmann MR, Mehalick AJ, Packer RL, Jenik PD (2011) MicroRNAs regulate the timing of embryo maturation in Arabidopsis. Plant Physiol 155:1871-1884. https://doi.org/10.1104/pp.110.171355

Wolters H, Anders N, Geldner N et al (2011) Coordination of apical and basal embryo development revealed by tissue-specific GNOM functions. Development 138:117-126. https://doi. org/10.1242/dev.059147

Xiao W (2006) DNA methylation is critical for Arabidopsis embryogenesis and seed viability. Plant Cell Online 18:805-814. https ://doi.org/10.1105/tpc.105.038836

Yamamoto Y, Kamiya N, Morinaka Y et al (2007) Auxin biosynthesis by the YUCCA genes in rice. Plant Physiol 143:1362-1371. https ://doi.org/10.1104/pp.106.091561

Yang J, Wu S, Li C (2013) High efficiency secondary somatic embryogenesis in Hovenia dulcis Thunb. through solid and liquid cultures. Sci World J 2013:1-6. https://doi.org/10.1155/2013/71875 4

Yunus IS, Liu Y, Nakamura Y (2016) The importance of SERINE DECARBOXYLASE1 (SDC1) and ethanolamine biosynthesis during embryogenesis of Arabidopsis thaliana. Plant J 88:559 569. https://doi.org/10.1111/tpj.13278
Zavattieri MA, Frederico AM, Lima M et al (2010) Induction of somatic embryogenesis as an example of stress-related plant reactions. Electron J Biotechnol 13:1-9. https://doi.org/10.2225/ vol13-issue 1-fulltext-4

Zhang C (2013) Heritable epigenetic variation and its potential applications for crop improvement. Plant Breed Biotechnol 1:307-319. https://doi.org/10.9787/PBB.2013.1.4.307

Zhang Z, Laux T (2011) The asymmetric division of the Arabidopsis zygote: from cell polarity to an embryo axis. Sex Plant Reprod 24:161-169. https://doi.org/10.1007/s00497-010-0160-x

Zhang M, Kimatu JN, Xu K, Liu B (2010) DNA cytosine methylation in plant development. J Genet Genom 37:1-12. https://doi. org/10.1016/S1673-8527(09)60020-5

Zhang Y, Clemens A, Maximova SN, Guiltinan MJ (2014) The Theobroma cacao $\mathrm{B} 3$ domain transcription factor $T c L E C 2$ plays a duel role in control of embryo development and maturation. BMC Plant Biol 14:106

Zhu T, Moschou PN, Alvarez JM et al (2014) WUSCHEL-RELATED HOMEOBOX $8 / 9$ is important for proper embryo patterning in the gymnosperm Norway spruce. J Exp Bot 65:6543-6552. https ://doi.org/10.1093/jxb/eru371

Zhu T, Moschou PN, Alvarez JM et al (2016) WUSCHEL-RELATED $H O M E O B O X 2$ is important for protoderm and suspensor development in the gymnosperm Norway spruce. BMC Plant Biol 16:1-14. https://doi.org/10.1186/s12870-016-0706-7

Publisher's Note Springer Nature remains neutral with regard to jurisdictional claims in published maps and institutional affiliations. 